\title{
The shelly fauna and biostratigraphy of the lower Cambrian (provisional series 2, stage 4) Evjevik Member, Ringstrand Formation in the Miøsa area, Norway
}

\author{
Magne Høyberget ${ }^{1}$, Jan Ove Røysi Ebbestad ${ }^{2}$, Bjørn Funke 3 \& Hans Arne Nakrem ${ }^{4}$ \\ ${ }^{1}$ Rennesveien 14, N-4513 Mandal, Norway. \\ ${ }^{2}$ Museum of Evolution, Uppsala University, Norbyvägen 16, SE-752 36 Uppsala, Sweden. \\ ${ }^{3}$ Gjelleråsveien 10, N-1481 Hagan, Norway. \\ ${ }^{4}$ Natural History Museum, University of Oslo, Pb.1172 Blindern, N-0318 Oslo, Norway. \\ E-mail corresponding author (Magne Høyberget): magne.hoyberget@mandal.kommune.no
}

\begin{abstract}
New, extensive fossil material collected in situ from the lower Cambrian Evjevik Member in the Mjøsa type area, southern Norway, allows a reevaluation of the faunal distribution and diversity of the 'Ornamentaspis' linnarssoni Zone. Described taxa include three holmiid, six ellipsocephalid and one eodiscoid trilobite in addition to five helcionelloid molluscs. A Holmia species with affinities to the Swedish H. lapponica is common in the Evjevik Member. Librigenae, thoracic segments and pygidia from the poorly known, but biostratigraphically important trilobite 'Ornamentaspis' linnarssoni (Kiær, 1917) are documented for the first time. The species is redescribed and transferred to Ellipsocephalus. Helcionelloid molluscs are represented by Helcionella antiqua (Kiær, 1917), Stenotheca norvegica (Resser, 1938), Mackinnonia puppis n. sp., Mackinnonia? sp. and Latouchella sp. These are similar to taxa reported from coeval strata at Gislövshammar in southern Sweden and may prove to have biostratigraphical potential. The Holmia kjerulfi Zone, the Ellipsocephalus linnarssoni Zone and the Comluella? scanica-Ellipsocephalus lunatus Zone are readily recognised in the Lower Allochthon of the Mjøsa area and are in this report treated as distinctive, successive zones. New illustrations are provided of the brachiopod Magnicanalis rotundata (Kiær, 1917), together with the enigmatic fossil Mongolitubulus Missarzhevsky, 1977, recorded for the first time in Norway.
\end{abstract}

Keywords: Trilobites, helcionelloids, lower Cambrian, biostratigraphy, Norway

Received 1. December 2014 / Accepted 16. April 2015 / Published online 8. July 2015

\section{Introduction}

The biozonation established for the upper part of the lower Cambrian in Scandinavia is based on the fossiliferous sequences in the Mjøsa area, southern Norway. The zonation comprises the Holmia kjerulfi Zone, known from the Tømten Member of the Ringstrand Formation, and the 'Ornamentaspis' linnarssoni Zone, characteristic of the Evjevik Member. An informal late early Cambrian Comluella? - Ellipsocephalus lunatus zone was distinguished by Nielsen \& Schovsbo (2011). The fauna and lithology of the Evjevik Member have repeatedly been referred to for more than a century, although the biostratigraphy has not been worked out based on outcrop studies. Various designations have been used for the 'O.' linnarssoni Zone during the last few decades: the Proampyx linnarssoni Zone (Bergström \& Ahlberg, 1981), Protolenus Zone (Moczydłowska et al., 2001; Moczydłowska, 2002), 'Ornamentaspis' linnarssoni Assemblage Zone (Axheimer et al., 2007), Holmia kjerulfi - 'Ornamentaspis' linnarssoni zone (Nielsen \& Schovsbo, 2011) and Ornamentaspis? linnarssoni Zone (Cederström et al., 2012). This zone is recognisable in numerous outcrops in southern Norway, southern Sweden and

Høyberget, M., Ebbestad, J.O.R., Funke, B. \& Nakrem, H.A. 2015: The shelly fauna and biostratigraphy of the lower Cambrian (provisional series 2 , stage 4) Evjevik Member, Ringstrand Formation in the Mjøsa area, Norway. Norwegian Journal of Geology 95, 23-56.

doi: http://dx.doi.org/10.17850/njg95-1-02.

(c) Copyright the authors.

This work is licensed under a Creative Commons Attribution 4.0 International License. 


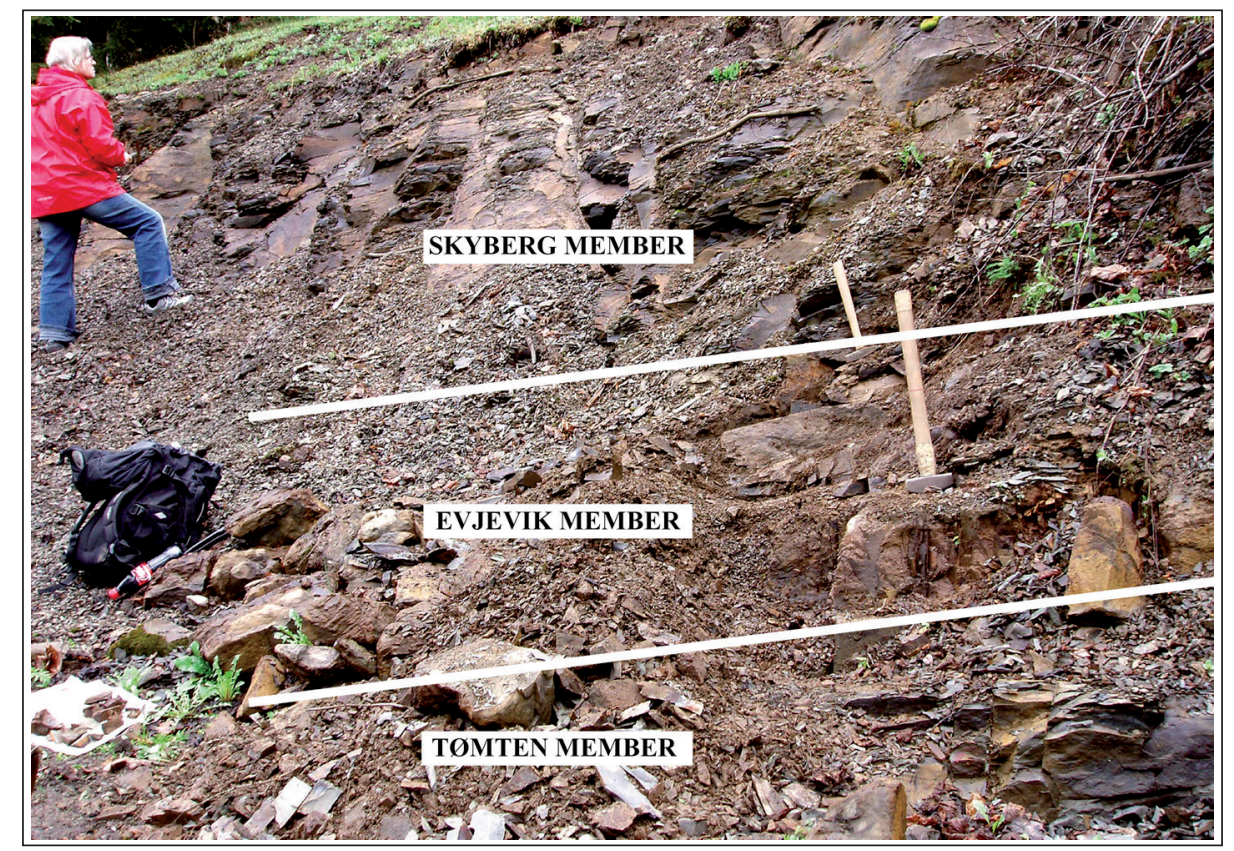

Figure 1. The hypostratotype section of the Evjevik Member at Skyberg, Ringsaker, Mjøsa area. The sledgehammer is resting on top of the lower bed, the small hammer on top of the upper bed. The uppermost metre of the underlying Tømten Member containing Holmia kjerulfi and Kjerulfia lata is partly exposed. The fossiliferous overlying Skyberg Member is fully exposed.

along the Caledonian front, overlying the Holmia kjerulfi Assemblage Zone within the lower Cambrian VergalianRausvian Stage (lower Cambrian provisional series 2, stage 4, see Nielsen \& Schovsbo, 2011, figs. 12, 13). The eponymous trilobite species Strenuella linnarssoni was originally described and figured by Kiær (1917) from the Strenuella Limestone (now the Evjevik Member) at
Tømten and Evjevik, based mostly on fragmentary and poorly preserved cranidia collected from loose limestone boulders. The highly fossiliferous Evjevik Member is well exposed at Skyberg Farm in Ringsaker (Fig. 1) recently designated as a hypostratotype section (Nielsen \& Schovsbo, 2007, p. 68).

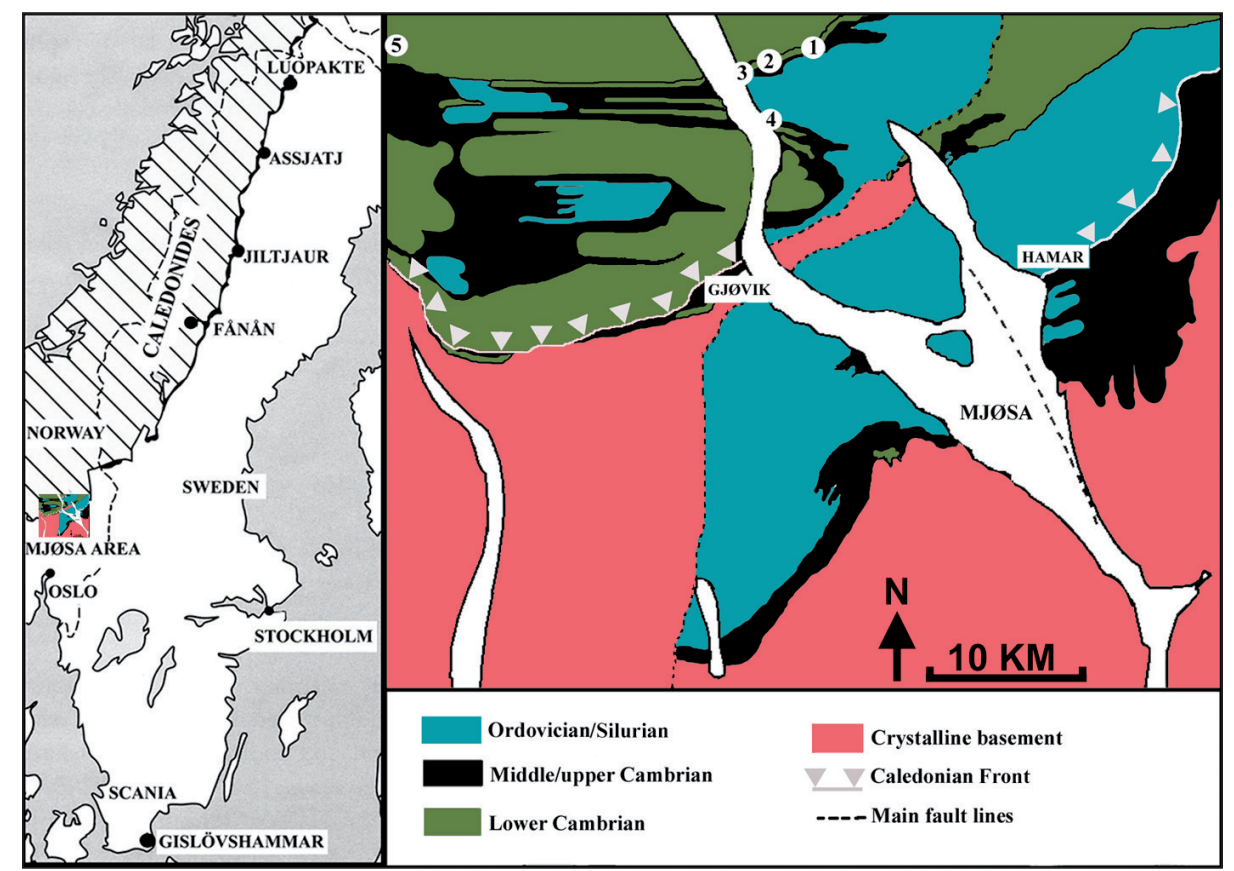

Figure 2. Map of the main Scandinavian lower Cambrian outcrops (to the left) and Cambro-Silurian deposits in the Mjøsa area, with numbered outcrops of the Evjevik Member (to the right). 1 - Skyberg Farm, 2 - Tømten Farm, 3 - Evjevika, 4 - Ringstrand, 5 - Finna River. 
The member is also recorded at Ringstrand and Evjevik along the eastern shoreline of Lake Mjøsa, at the classic locality Tømten Farm, and by the river Finna in Snertingdalen on the west side of Lake Mjøsa (Fig. 2). The stratotype section at Evjevik is normally inaccessible due to high water level in the lake and is now covered with mud. The Tømten exposure was protected by law in 1988 and has since then been totally covered. It is extremely difficult to extract fossils from the splintery limestone, and the best specimens are found in decalcified rocks on the beach at Ringstrand and Skyberg.

New and extensive material collected from in situ strata in the type area allows evaluation of the faunal distribution and diversity of the 'O.' linnarssoni Zone and to explore the biostratigraphical implications. This paper also describes the trilobite and helcionelloid mollusc fauna of the 'O.' linnarssoni Zone from the type area in Norway, most importantly placing 'O.' linnarssoni (Kiær, 1917) within Ellipsocephalus. Traditionally, trilobites have proved to be one of the best tools for biostratigraphical correlation of Cambrian strata in Baltoscandia, but helcionelloids may prove to be an important addition for future studies, including intercontinental correlations.

\section{Geological setting and faunal content}

The Lower Allochthon in the Mjøsa area is the lower part of a series of nappes and may have been tectonically displaced up to $100 \mathrm{~km}$ from the northwest during the Caledonide orogeny. The studied area is located close to the Caledonian front (Fig. 2). The Evjevik Member, which is $1.1 \mathrm{~m}$ thick in the type area, is part of the presumably 50-60 m-thick Ringstrand Formation that comprises the Brennsætersag, Redalen, Tømten, Evjevik and Skyberg members as defined by Nielsen \& Schovsbo (2007). The Evjevik Member has previously been termed the Strenuella Limestone (Kiær, 1917, p. 96) and the Evjevik Limestone/Stage $1 b \beta$ (Skjeseth, 1963). It is overlying the up to $40 \mathrm{~m}$-thick, greenish-grey mudstone of the Tømten Member, previously termed the Holmia Shale (Kiær, 1917). The Evjevik Member consists of two bioclastic silty limestone beds intercalated by a siliciclastic mudstone bed and is known only from the Lower Allochthon in the Mjøsa area. Detrital quartz grains in the limestones have been calculated from counting and measuring of grains in thin-sections. Average quartz grain size is $0.047 \mathrm{~mm}$, with a few grains $(<2 \%)$ within the very fine sand fraction. The member represents a shallower and better oxygenated facies within the Ringstrand Formation, with reworked and disarticulated fossil remains. For this study, a more detailed petrological or sedimentological analysis has not been undertaken.

The faunal diversity of the Evjevik Member is here shown to be considerably higher than previously reported and the faunal composition is found to be slightly different in the two beds (Fig. 3). The lower boundary of the member is defined at the base of a $25-30 \mathrm{~cm}$-thick bed of bioclastic, silty limestone weathering to a brown colour (herein referred to as the lower limestone bed or lower bed). This limestone bed contains the brachiopod Magnicanalis rotundata (Kiær, 1917) in abundance (Fig. 4G), the trilobites Ellipsocephalus linnarssoni (Kiær, 1917), E. gripi (Kautsky, 1945) and dense accumulations of very fragmented holmiid sclerites representing Holmia kjerulfi (Linnarsson, 1871), H. cf. lapponica Ahlberg \& Bergström, 1983 and Kjerulfia lata Kiær, 1917, together with the helcionelloid taxa Helcionella antiqua (Kiær, 1917), Stenotheca norvegica (Resser, 1938), Mackinnonia puppis n. sp. and Latouchella sp.

The lower bed is followed by $60 \mathrm{~cm}$ of grey, siliciclastic mudstone containing Holmia cf. lapponica, Strenuaeva spinosa Ahlberg \& Bergström, 1978, Magnicanalis rotundata, linguliform brachiopods and hyoliths.

The upper boundary of the Evjevik Member is drawn at the top of a second, $20 \mathrm{~cm}$-thick layer of bioclastic, silty limestone (herein referred to as the upper limestone bed or upper bed). This upper bed is essentially a coquina

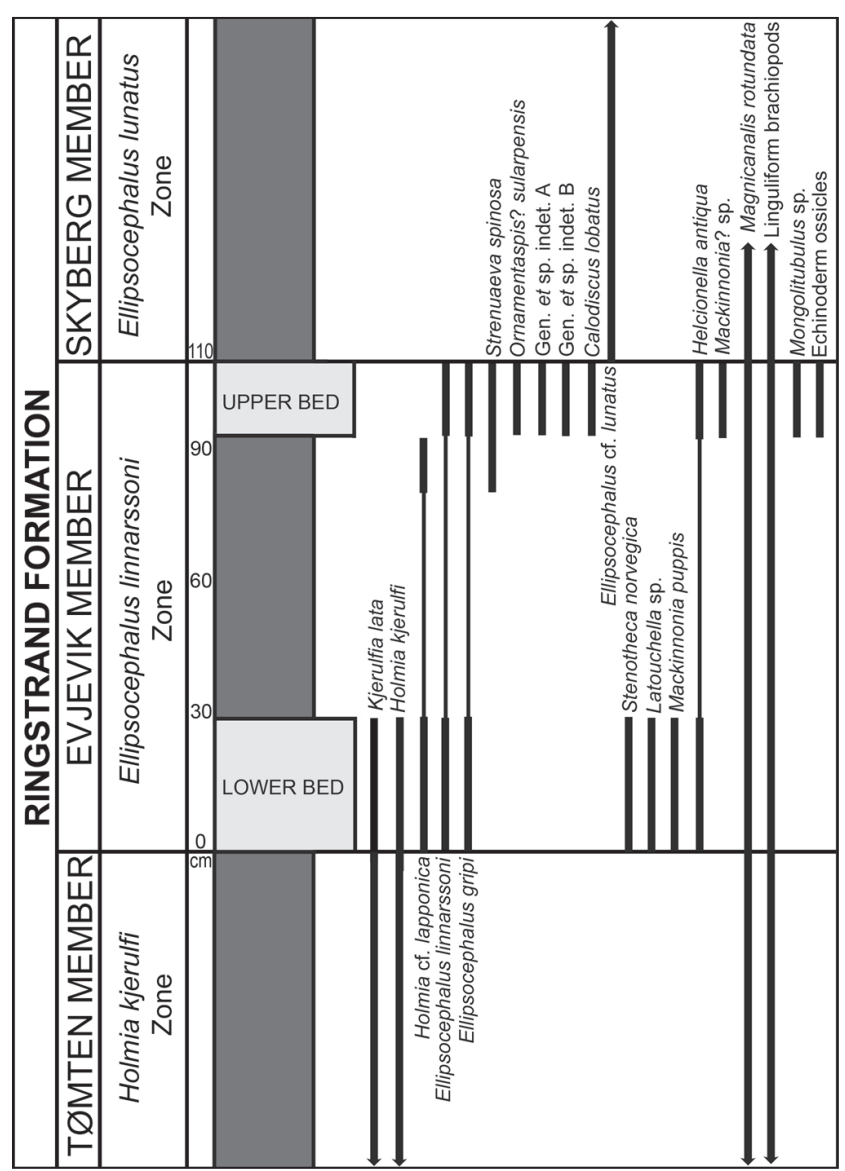

Figure 3. Section diagram of the Evjevik Member at Skyberg Farm with faunal content and range chart. Thick bars: fossil occurrences. Arrow heads: fossil occurrences continuing beyond the diagram. Dark grey: siliciclastic mudstone. Light grey: bioclastic, silty limestone. The $0 \mathrm{~cm}$ level is set at the base of the lower bed. 
of sclerites (Fig. 4A) from E. linnarssoni, E. gripi, Ornamentaspis? sularpensis (Ahlberg \& Bergström, 1978), $S$. spinosa and rare occurrences of the eodiscoid trilobite Calodiscus lobatus (Hall, 1847). M. rotundata occurs scattered together with rare specimens of the helcionelloid Helcionella antiqua and Mackinnonia? sp. Thin-sections have revealed echinoderm ossicles (Fig. 4B) and fragments of linguliform brachiopods.
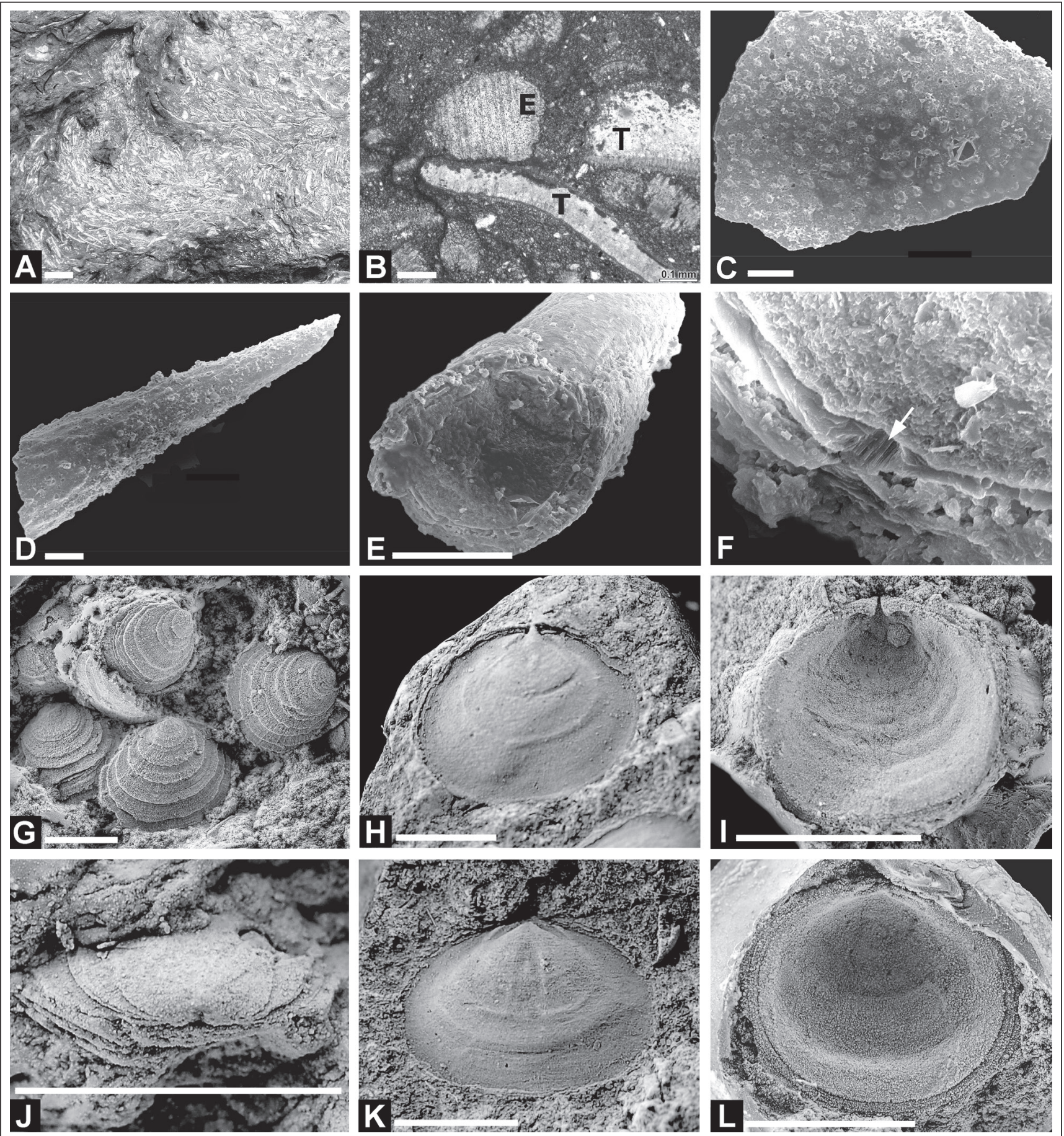

Figure 4. (A) Photo of the in situ upper bed in the Evjevik Member, showing cross-sectioned coquinas of ellipsocephalid sclerites as pale lines. (B) Thinsection PMO 202.791 of micritic matrix showing quartz grains (white dots), echinoderm ossicles - E, and trilobite sclerites with microborings - T. (C-F) Small shelly fossils dissolved from the upper bed, resembling Mongolitubulus Missarzhevsky, 1977. (C) Fragment of carapace, PMO 221.842/1. (D) Tip of a broken spine, PMO 221.842/2. (E) Broken spine showing the thickness of the wall, PMO 221.842/3 (F) Close-up of E showing layered microstructure. Note fibrous layer (arrow). (G-L) Magnicanalis rotundata Kicer, 1917. (G) Latex cast of external moulds with imbricated growth lines, lower bed, PMO 227.614 (counterpart PMO 227.614/2). (H) Internal mould of pedicle valve, PMO 227.615/1. (I) Latex cast of internal mould of pedicle valve, PMO 227.616. (J) Latex cast of external mould of the umbonal area, with larval shell, PMO 227.617. (K) Internal mould of brachial valve showing muscle scars and septum, PMO 227.615/2. (L) Latex cast of internal mould of brachial valve, PMO 227.618. All specimens collected at Skyberg Farm. Scale bars in (A), G-L: 5 mm. Scale bars in (B-E): $100 \mu \mathrm{m}$. 
Acetic acid treatment gave small shelly fossils (Fig. $4 \mathrm{C}-\mathrm{F}$ ) resembling spines and carapace fragments of the enigmatic Mongolitubulus Missarzhevsky, 1977, recently interpreted as spines from bradoriid arthropods (Skovsted \& Peel, 2001; Skovsted, 2005; Skovsted et al., 2006; Topper et al., 2007, 2013), lobopodians (Dzik, 2003; Caron et al., 2013) or eodiscoid trilobites (Li et al., 2012).

Overlying the Evjevik Member are 7 metres of fossiliferous mudstone termed the Skyberg Member (Nielsen \& Schovsbo, 2007). This unit is so far known only from exposures at Skyberg Farm and contains Ellipsocephalus cf. lunatus Bergström \& Ahlberg, 1981 as well as other trilobite species co-occurring with a diverse fauna comprising linguliform brachiopods, bradoriids, hyoliths, tubular shells, lapworthellids and other small shelly fossils.

\section{Biostratigraphy}

The biostratigraphy of the Evjevik Member has not previously been worked out based on in situ exposures. Nikolaisen (1986, p. 305) recognised the lower bed to be present at Tømten, while Kiær (1917) repeatedly referred to loose boulders of a fossiliferous sandy limestone from the Holmia Shale. Kiær's list of fossils (Kiær, 1917, p. 95) from these boulders corresponds to the fauna recognised here in the lower bed at Skyberg. Kiær emphasised the faunal differences between the Holmia Shale and the sandy limestone with Strenuella (now Ellipsocephalus) linnarssoni. He was apparently not aware of the stratigraphic level of the loose boulders, although when discussing the fossil content he refers it to a horizon that "probably lies above the real Holmia shales", noting the similarity to the Strenuella Limestone "somewhat higher up" (Kiær, 1917, p. 40).

Münster (1900, p. 22-23) reported fragments of $H$. kjerulfi in the lower bed at Evjevik, and Kiær (1917, pl. 8 , figs. 2, 3) figured two fragmentary, meraspid cranidia of this species from his sandy limestone. Ahlberg \& Bergström (1978, p. 28) reported a $50 \mathrm{~cm}$-thick, strongly weathered limestone at Skyberg containing Proampyx linnarssoni (Kiær, 1917) and probably Kjerulfia lata, but the presence of two separate limestone beds or associated fauna was not mentioned.

Bergström \& Ahlberg (1981) indicated that the highly condensed $32 \mathrm{~cm}$-thick upper part of the Gislöv Formation in Scania, Sweden, could be subdivided into a $19 \mathrm{~cm}$ lower part containing Proampyx linnarssoni and a $13 \mathrm{~cm}$ upper part with Ellipsocephalus lunatus and Comluella? scanica Ahlberg \& Bergström, 1978. E. linnarssoni, E. gripi and Strenuaeva spinosa have recently been reported from several localities in the lower part of the Ellipsocephalus linnarssoni Zone in central and southern Swedish Lapland, and S. spinosa is associated with
E. linnarssoni and O.? sularpensis in Scania, southern Sweden (Cederström et al., 2012). Interestingly, Ellipsocephalus linnarssoni, E. gripi, Ornamentaspis? sularpensis and Strenuaeva spinosa are all associated in the Evjevik Member in the Mjøsa area.

Nielsen \& Schovsbo (2007, fig. 2) correlated the Evjevik Member with the bioclastic limestone in the $32 \mathrm{~cm}$ upper part of the Gislöv Formation at Gislövshammar, southern Sweden. Based on eodiscoid trilobites, Axheimer et al. (2007, p. 956) correlated the 'Ornamentaspis' linnarssoni Assemblage Zone with the Hupeolenus Zone in Newfoundland, Canada and the 'Protolenus' Zone in England, ideas initiated already by Kiær (1917).

In their work on sequence-stratigraphic correlation in Scandinavia, Nielsen \& Schovsbo (2011, p. 220) united the Holmia kjerulfi Zone and the lower part of the 'Ornamentaspis' linnarssoni Zone, but preferred to treat this combined zone as informal, pending revision of the trilobite ranges in the Mjøsa area. The merging was based on a record of 'O.' linnarssoni in the lower part of the highly condensed Gislöv Formation (Nielsen \& Schovsbo, 2007, p. 222, 239; Cederström et al., 2012) and one possible specimen co-occurring with E. gripi from the grey mudstone of the Gärdsjön Formation in Fånån, Jämtland (Cederström et al., 2009, unfigured), both occurrences interpreted by Nielsen \& Schovsbo to be coeval with the lower part of the underlying Tømten Member in the Mjøsa area; thus suggesting that the distribution of the $H$. kjerulfi and 'O.'linnarssoni zonal assemblages reflects biofacies rather than temporal differences. However, a diverse and abundant fauna of helcionelloid molluscs from this E. linnarssoni-bearing lower part of the Gislöv Formation (Ebbestad et al., 2009) is similar to the presently described material from the lower limestone bed in the Evjevik Member. This strongly suggests that the $40 \mathrm{~cm}$-thick laminated siltstone section with calcareous nodules in the lower part of the Gislöv Formation at Gislövshammar, Sweden, and the lower bed in the Evjevik Member are contemporaneous. This suggestion may be strengthened by the several co-occurring trilobite species with a short stratigraphic range within the $E$. linnarssoni Zone in Scandinavia.

Extensive sampling has revealed that Ellipsocephalus linnarssoni is found exclusively in the bioclastic silty limestones of the Evjevik Member in the Mjøsa area, which also revealed a distinct change in content of trilobite species compared to the underlying Tømten Member.

Cederström et al. (2012) reported H. kjerulfi and O.? linnarssoni to be stratigraphically separated in a series of siltstone and mudstone sections along the Caledonian front, although the latter is associated with other holmiids, which also indicates temporal rather than biofacies differences. 
The overlap of the two zonal species in the lower bed in the Evjevik Member in the Mjøsa area is here considered to reflect reworking of older deposits. This is supported by the abundant but extremely fragmented olenellid remains compared to the well preserved ellipsocephalid sclerites, brachiopods retaining delicate details and complete, fragile helcionelloid shells. Álvaro et al. (2010, p. 62) recognised that the substrate of corresponding deposits in Scania, Sweden (the Gislöv Formation), was winnowed by waves and storm episodes and the fossils were reported to be predominantly fragmented and abraded with random orientation.

Regrettably, search for acritarchs in the Evjevik Member has been unsuccessful (Vidal \& Nystuen, 1990).

Nielsen \& Schovsbo (2011, p. 243) suggested that the upper bed of the Evjevik Member represents the base of the stratigraphically higher Comluella?-Ellipsocephalus lunatus Assemblage Zone, but the trilobite content demonstrates that this bed belongs to the Ellipsocephalus linnarssoni Zone. Despite extensive search, E. lunatus has not been recorded from the upper limestone bed in the Evjevik Member. Search in the overlying Skyberg Member shows that the $7 \mathrm{~m}$-thick mudstone contains a diverse shelly fauna including common occurrences of Ellipsocephalus cf. lunatus, which is suggestive of the Comluella?-Ellipsocephalus lunatus Assemblage Zone. However, Comluella? representatives have so far not been found in the Mjøsa area.

The Holmia kjerulfi Zone and the Ellipsocephalus linnarssoni Zone are readily recognised in the Lower Allochthon of the Mjøsa area and in Sweden and are here maintained as separate biozones, following Cederström et al. (2012, p. 161). The base of the Ellipsocephalus linnarssoni Zone is defined at the First Appearance Datum (FAD) of E. linnarssoni and the top of the zone defined by the appearance of Ellipsocephalus cf. lunatus, within the stratotype section at Skyberg Farm, Miøsa area. GPS coordinates: UTM32 6755483N 596883E.

\section{Terminology and material}

Trilobite descriptive terminology follows that of Whittington (1997). The bulk of the material studied in this paper was collected during annual fieldwork 19952012 by the authors supplemented with the Kiær Collection in the Natural History Museum, Oslo, Norway. The non-flattened material consists of approximately 200 ellipsocephalid cranidia, 20 librigenae, abundant thoracic remains and 4 pygidia of well-preserved specimens in full relief, several with the exoskeleton partially preserved. Most of the material shows signs of tectonic distortion. The total cranidial length (Le in Fig. 7) and the length of the cranidial anterior area (Le3) seen in dorsal view are easily shortened or lengthened by distortion or taphonomy and should not be used for comparisons. The true length of the anterior area (LAA) is therefore measured. Except for LAA, the measurements are taken in one plane. All figured specimens referred to by a PMO number are housed in the palaeontological collections at the Natural History Museum, Oslo (formerly Paleontologisk Museum, Oslo). Figured specimens abbreviated SGU are housed at the Swedish Geological Survey, Uppsala, and NRM are found in the Swedish Natural History Museum, Stockholm. The prefix LO refers to specimens stored at the Earth Science department at Lund University, Sweden. Several type specimens are refigured herein for comparison.

\section{Systematic palaeontology}

Phylum Arthropoda Latreille, 1829

Class Trilobita Walch, 1771

Family Holmiidae Hupé, 1953

Subfamily Holmiinae Hupé, 1953

Genus Holmia Matthew, 1890

Type species: By monotypy (Matthew, 1890, note on p. 160), Paradoxides Kjerulfi Linnarsson, 1871, p. 790, pl. 16, figs. 1-3, from the lower Cambrian provisional series 2, stage 4, Tømten Member of the Ringstrand Formation at Tømten Farm in Ringsaker, Mjøsa area, southern Norway.

Remarks: Matthew (1889, p. 76) found that Paradoxides Kjerulfi as discussed by Holm (1887) represented a genus intermediate between Paradoxides and Olenellus, and remarked in a footnote on the same page that the new genus should bear Holm's name. The following year, Matthew (1890, note on p. 160, issued in May) suggested to henceforth call the genus Holmia. Marcou (1890, p. 366, issued in June), maintained the use of Holmia in his publication. The genus and its phylogeny were discussed in detail by Palmer \& Repina (1993) and Lieberman (1999).

\section{Holmia kjerulfi (Linnarsson, 1871)}

Figs. 5A-C, 6A-D, F

1973 Holmia kjerulfi (Linnarsson) - Bergström, p. 287.

1984 Holmia kjerulfi (Linnarsson) - Ahlberg, p. 256.

1986 Holmia kjerulfi (Linnarsson) - Nikolaisen, p. 306, fig. 1A-E.

1988 Holmia kjerulfi (Linnarsson) - Whittington, p. 579, figs. 2, 3 .

1990 Holmia kjerulfi (Linnarsson) - Whittington, p. 37, figs. 13-19.

1993 Holmia kjerulfi (Linnarsson) - Palmer \& Repina, p. 25, fig. 6.1.

1997 Holmia kjerulfi (Linnarsson) - Palmer \& Repina, p. 414, fig. 261,1.

1998 Holmia kjerulfi (Linnarsson) - Lieberman, p. 67. 1999 Holmia kjerulfi (Linnarsson) - Lieberman, p. 75. 

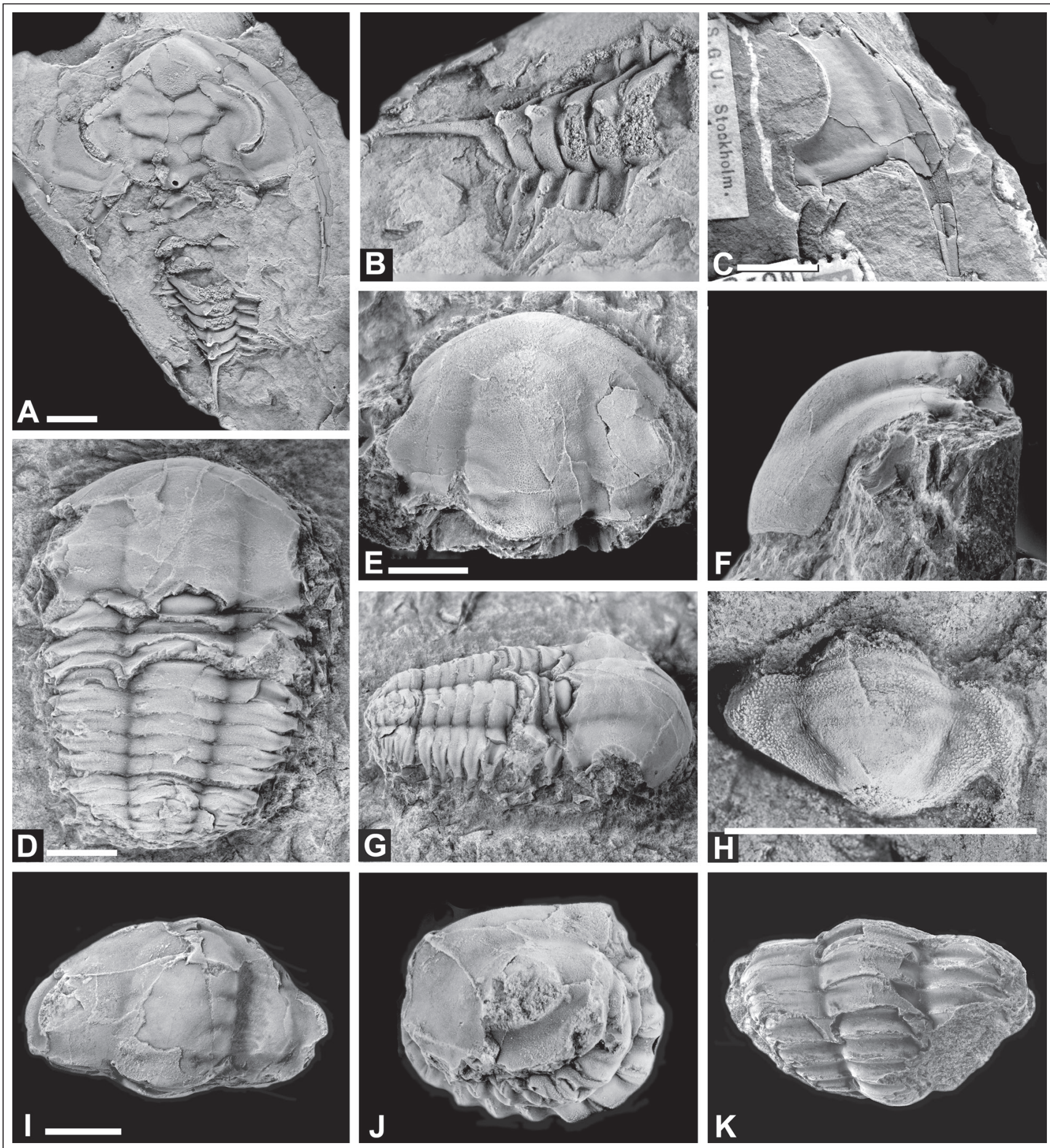

Figure 5. (A-C) Holmia kjerulfi (Linnarsson, 1871). (A) Dorsal view of a latex cast of the lectotype, SGU 5329b. (B) Close-up of (A). Note prominent axial spines. (C) Dorsal view of genal area, paralectotype SGU 5331a. Note acute inner genal spine angle. Coll.: G. Linnarsson, 1870, Tømten Member at Tømten Farm, Ringsaker, Mjøsa area. Figured by Linnarsson (1871, pl. 16, figs. 1, 3). (D-K) Ellipsocephalus gripi (Kautsky, 1945), specimens from Kautsky's type series, Mt. Assjatj, Sweden. (D, G) Dorsal and oblique lateral view of carapace, NRM Ar9042, with thirteen thoracic segments preserved (pl. 14.6 in Kautsky, 1945). (E, F) Cranidium, NRM Ar9012 in dorsal and lateral view. Note the long anterior area (pl. 15.5 in Kautsky, 1945). (H) Pygidium, NRM Ar9035 with marginal spine on right side (pl. 13.9 in Kautsky, 1945). (I-K) Enrolled specimen, NRM Ar9030, anterior area broken off (pl. 15.6, 7 in Kautsky, 1945). Scale bars: 5 mm.

2002 Holmia kjerulfi (Linnarsson) - Lieberman, p. 699, fig. 2, node 87.

2012 Holmia kjerulfi (Linnarsson) - Cederström et al., fig. 6C.

See Bergström (1973) for an extensive synonymy list on earlier references.
Type specimen: Lectotype SGU 5329a, b, selected by Palmer \& Repina (1993, p. 25). Original of Linnarsson (1871, pl. 16, fig. 1). From the lower Cambrian provisional series 2, stage 4, Tømten Member of the Ringstrand Formation at Tømten Farm in Ringsaker, Mjøsa area, Norway. Refigured here in Figs. 5A, B \& 6A. 
New material: Two partially preserved genae, PMO 227.619, PMO 227.621 and one partial genicranium, PMO 227.620 from the lower limestone bed, Evjevik Member at Skyberg.

Remarks: The species was thoroughly described in the classical work of Kiær (1917). Palmer \& Repina (1993, p. 26, fig. 6.1) provided a diagnosis of the species and figured a paratype specimen. The refigured type material herein has previously been illustrated only as a line drawing by Linnarsson (1871). The species is common in the Tømten Member at several localities in the Mjøsa area and in the lower bed of the Evjevik Member as fragmented sclerites.

\section{Holmia cf. lapponica Ahlberg \& Bergström, 1983} Fig. 6E, G-P

\section{cf. 1983 Holmia lapponica n. sp. Ahlberg \& Bergström,} p. 242 , fig. $2 \mathrm{~A}, \mathrm{~B}$.

cf. 1986 Holmia lapponica Ahlberg \& Bergström Ahlberg et al., p. 108, fig. 5.

cf. 2012 Holmia lapponica Ahlberg \& Bergström Cederström et al., fig. 6B.

Type specimen: Holotype SGU Type 1231, an external mould of an almost complete specimen from a loose boulder found at the shore of Lake Långvattnet near Storuman in southern Swedish Lapland, probably deriving from the Grammajukku Formation.

Material: Three partly preserved holaspid cephala, PMO 227.623-PMO 227.625; three meraspid cephala, PMO 227.629-227.631; one cephalon with five thoracic segments, PMO 227.626; one nearly complete meraspid specimen, PMO 227.528 and one rostral plate with attached hypostome, PMO 227.627, all collected from the mudstone bed in the Evjevik Member at Skyberg. One genal fragment, PMO 227.622 is collected from the lower limestone bed.

Discussion: A species of Holmia resembling H. lapponica described from Swedish Lapland is found in the Evjevik Member. However, a revision of the many unassigned Scandinavian Holmia taxa is needed to clarify the affinity of this form.

H. lapponica is characterised by the proportionally large anterior glabellar lobe and wide inner genal spine angle. The genal spines are stout and the posterior border is straight and without a metagenal spine, and the pleural spines are long. In H. kjerulfi, the posterior border furrow runs in an oblique anterior direction laterally from the metagenal ridge and the inner genal spine angle is acute (Fig. 6A-C), whereas this furrow in $H$. cf. lapponica is directed obliquely rearwards from the metagenal ridge (Fig. 6E, G, I, J) and the inner genal spine angle is wide. $H$. cf. lapponica has a longer preglabellar area and the genal spines are long compared to $H$. kjerulfi. Further, the surface on the cephalon and hypostome is covered with a distinct, raised network of lines. Coarse terrace lines cover the rostral plate, the ventral and dorsal sides of the long genal spines and are also present along the cephalic border. Meraspids show distinct metagenal ridges (Fig. $6 \mathrm{~N}-\mathrm{P})$ and macropleural spines on the second segment (Fig. 6M).

\section{Genus Kjerulfia Kiær, 1917}

Type species: By original designation, Kjerulfia lata Kiær, 1917, pp. 71-81, text-figs. 12, 14, 15; pls. 9-13, 14, figs. 1-21, from the lower Cambrian provisional series 2, stage 4, Tømten Member of the Ringstrand Formation at Tømten in Ringsaker, Mjøsa area, Norway.

Remarks: The genus is characterised by narrow extraocular cheeks and wide lateral border, laterally positioned intergenal node and commonly short, broad-based genal spine. Ahlberg et al. (1986) and Lieberman (1999) placed Kjerulfia within the subfamily Holmiinae, while Palmer \& Repina (1993) assigned the genus to Calaviinae.

\section{Kjerulfia lata Kiær, 1917}

Fig. 6Q

1987 Kjerulfia lata Kiær - Nikolaisen \& Henningsmoen, pp. 62-64, figs. 3, 7A-C.

1993 Kjerulfia lata Kiær - Palmer \& Repina, p. 27, figs. $6.9,10$.

Figure 6. (A-D, F) Holmia kjerulfi (Linnarsson, 1871). (A) Close-up of a latex cast of the lectotype, SGU 5329b from the Tømten Member at Tømten Farm, Ringsaker. (B) Genal area, PMO 227.619. Lower bed, Evjevik Member, Skyberg Farm. (C) Partial genal area (associated with several sclerites of E. linnarssoni on PMO 98116). Evjevik Member, Østre Åbu, Rena. Coll.: G. Henningsmoen, 1976. (D) Partial genal area, PMO 227.621. Lower bed, Evjevik Member, Skyberg Farm. Note oblique anteriorly directed posterior border and acute inner genal spine angle in $A-D$. (F) Internal mould of poorly preserved genicranium, PMO 227.620. Lower bed, Skyberg Farm. (E, G-P) Holmia cf. lapponica Ahlberg \& Bergström, 1983. (E) Partial genal area, PMO 227.622, showing wide inner genal spine angle and oblique posteriorly directed posterior border. Picture mirrored. Lower bed, Evjevik Member, Skyberg Farm. (G) Latex cast of external mould of genicranium, PMO 227.623/2. Note very long genal spine and wide inner genal spine angle. (H) Internal mould of partly preserved genicranium, PMO 227.624. (I) Internal mould of tectonically shortened genicranium, PMO 227.625. (J) Internal mould of partly preserved genicranium, PMO 227.626, with five dislocated thoracic segments (LO and L1 lacking). (K) Close-up of latex cast of external mould, PMO 227.624/2, (same specimen as $H$ ) with distinct surface network. (L) Latex cast of rostral plate with attached hypostome, PMO 227.627/2, showing distinct terrace lines and network. (M) Nearly complete meraspid stage with fourteen thoracic segments, PMO 227.628. (N) Latex cast of early meraspid genicranium, PMO 227.629. (O) Meraspid genicranium, PMO 227.630. (P) Latex cast of meraspid genicranium, PMO 227.631/2. (G-P) Mudstone bed, Evjevik Member, Skyberg Farm. (Q) Kjerulfia lata Kiwer, 1917. Latex cast of external mould of partly preserved genicranium, PMO 227.632/2. Lower bed, Skyberg Farm. Scale bars on B-E, M-P: $2 \mathrm{~mm}$. Scale bars on A, F-L, Q: $5 \mathrm{~mm}$. 

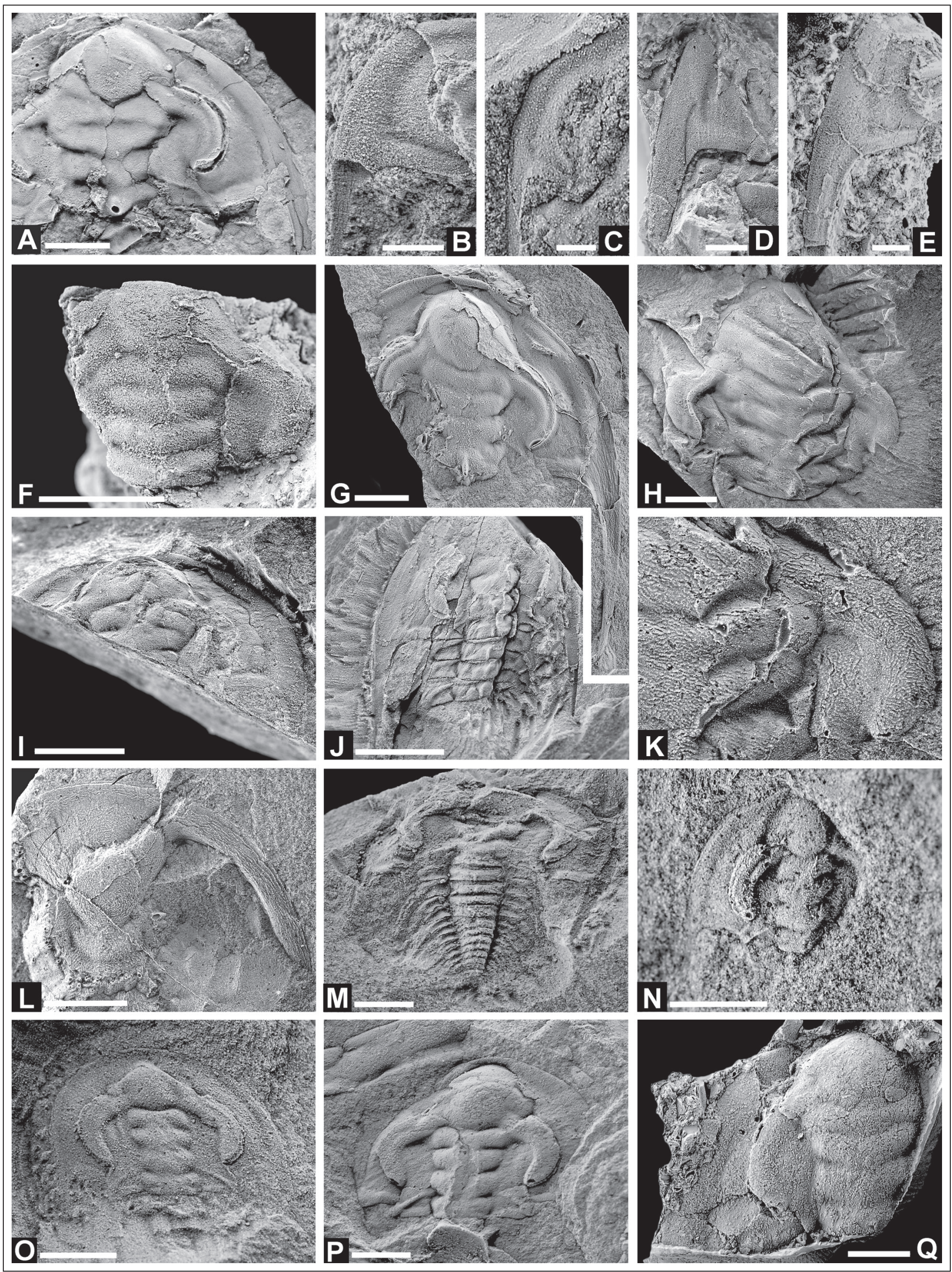
1997 Kjerulfia lata Kiær - Palmer \& Repina, p. 420, figs. 263, 2a, b.

1998 Kjerulfia lata Kiær - Lieberman, p. 67.

1999 Kjerulfia lata Kiær - Lieberman, pp. 81-82.

2002 Kjerulfia lata Kiær - Lieberman, p. 699, fig. 2, node 83.

2012 Kjerulfia lata Kiær - Cederström et al., fig. 6A. See Nikolaisen \& Henningsmoen (1987) for full synonymy.

Type specimen: Lectotype PMO 61376, selected by Nikolaisen \& Henningsmoen (1987). An incomplete genicranium figured by Kiær (1917, pl. 10, fig. 1), from the Tømten Member at Tømten Farm, Ringsaker, Mjøsa area.

New material: One partial genicranium, PMO 227.632, internal and external moulds, from the lower limestone bed at Skyberg.

Remarks: This species is well known from the Tømten Member in the Mjøsa area (Kiær, 1917) and additional material was collected from the very top of the Tømten Member and from the lower bed of the Evjevik Member at Skyberg during the present fieldwork. Nikolaisen (1986) figured a partial genicranium from the lower bed of the Evjevik Member at Tømten. A few specimens have also been found at the Digermulen Peninsula in northern Norway (Nikolaisen \& Henningsmoen, 1987; Ebbestad et al., 2014). Nikolaisen \& Henningsmoen (1987, pp. 62-64) provided a detailed description and extensive synonymy list. Lieberman (1999) excluded several other species assigned to the genus (compare list of species in Nikolaisen \& Henningsmoen, 1987); although not all possible Kjerulfia taxa were considered. Lieberman (1999, p. 81) erroneously stated that because the partial thorax of the paratype figured by Palmer \& Repina (1993, fig. 6.10) is completely disarticulated from any cephalic material, it is impossible to determine the specimen's assignment. This specimen (PMO 73170), however, shows the posterior part of the genicranium with the significant genal spine, intergenal ridge, posterior end of the eye lobe, width of the lateral border and the direction of the posterior margin. Kiær (1917, p. 79) noted the presence of long-eyed and short-eyed morphs in his material and a future study may separate these as two distinct species.

\section{Family Ellipsocephalidae Matthew, 1887}

Subfamily Ellipsocephalinae Matthew, 1887

Remarks: There has been some controversy regarding classification of ellipsocephalids at species, generic, subfamilial and familial level (Öpik, 1975; Ahlberg \& Bergström, 1978; Geyer, 1990; Jell, 1990; Westrop \& Landing, 2000). Glabellar outline has been used as one of the most important diagnostic features by many authors. Westrop \& Landing $(2000$, p. 863$)$ questioned the utility of diagnostic glabellar characters and emphasised the use of a parsimony analysis to solve the problem. The combined morphology of the spines and furrows in the cephalon, thorax and pygidium, together with cranidial convexity and glabellar features, all seem to be important diagnostic characters at the generic level.

More than 20 ellipsocephalid taxa endemic to Scandinavia have been described from the lower Cambrian (Ahlberg \& Bergström, 1978; Bergström \& Ahlberg, 1981; Ahlberg, 1979, 1983a, 1984), but the distinction between taxa is difficult due to fragmentary specimens, tectonic distortion and different preservation in mudstone and limestone. Additionally, there is a distinct difference between internal moulds and specimens with the thick exoskeleton preserved, masking furrows and other details. The same species may therefore show a large variation in proportions, convexity and furrow impressions, see e.g., Kautsky (1945, pl. 14, figs. 6, 7; pl. 15, figs. 1-4) and Żylińska et al. (2013). Several of the Scandinavian ellipsocephalid species are rare with few and fragmentary specimens where growth stages are unknown. Re-examination of the Kiær Collection in the Natural History Museum, Oslo, has shown that the bulk of the material is too distorted and weathered to be identified at species level with certainty.

Kautsky established the subgenus Strenuella (Ellipsostrenua) on the basis of Strenuella gripi, later elevated to generic rank by Henningsmoen (1959). This classification was subsequently followed by Sdzuy (1961), Rushton (1966), Poulsen (1969), Lendzion (1972), Bergström (1973) and Geyer (1990), but Ahlberg \& Bergström (1978) regarded the taxon as a junior synonym of Ellipsocephalus. A future study of the Scandinavian ellipsocephalids should be seen in affinity with the relatively new genera-concepts established for western Gondwanan ellipsocephalids. This has been initiated by Geyer (1990), who reassigned most of the Scandinavian Proampyx species (see Ahlberg \& Bergström, 1978) to Ornamentaspis and erected a new genus, Issafeniella, to which the well-known Scandinavian species Strenuaeva spinosa may be assigned. Geyer et al. (2004) described two new trilobite species, Epichalnipsus anartanus and Berabichia erratica, from erratic boulders supposedly deriving from the File Haidar Formation of southern Sweden. These taxa show affinities to western Gondwana and Geyer et al. (2004) also tentatively assigned Proampyx rotundata (Kiær, 1917) to Berabichia. The lower Cambrian trilobite fauna from the Holy Cross Mountains in Poland consists of holmiids with strong Scandinavian affinities, while the associated ellipsocephalids show similarity to those found in West Gondwana (Żylińska, 2013, p. 62). Żylińska \& Masiak (2007) and Żylińska \& Szczepanik (2009) revised the lower and middle Cambrian ellipsocephalids from Poland and transferred several species of Strenuaeva, Ellipsocephalus and Comluella to the West Gondwanan genera Berabichia, Issafeniella, Ornamentaspis, Kingaspis and Kingaspidoides. Future studies of the Scandinavian ellipsocephalids may result in a major revision of the older genera-concept for Scandinavian taxa. 


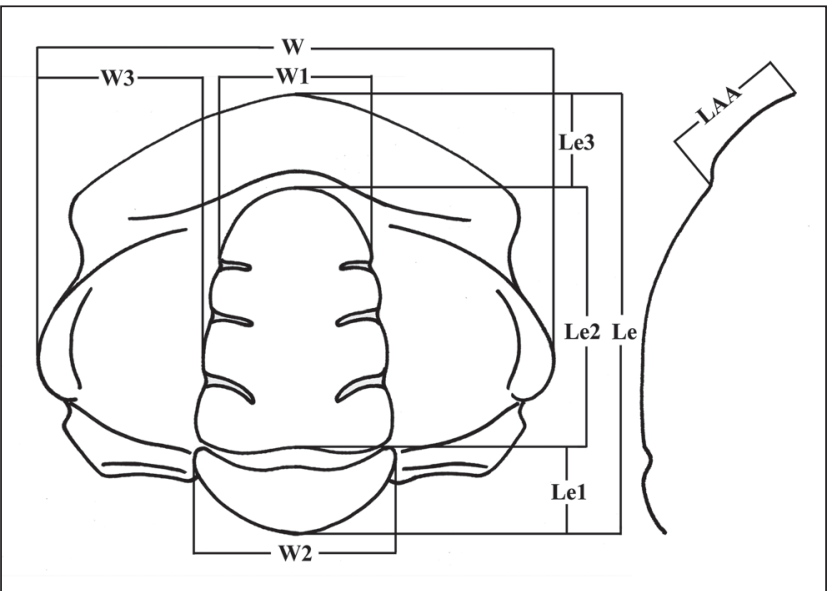

Figure 7. Diagram showing standard measurements on ellipsocephalid cranidia, modified from Ahlberg \& Bergström (1978) and Żylinska et al. (2013). Abbreviations: Le - total length of cranidium, Le1 - Length of occipital lobe, including the occipital furrow, Le2 - length of the glabella, excluding the occipital lobe, Le3 - length of the anterior area, including the preglabellar furrow, $L A A$ - true length of the anterior area in lateral view, $W$ - total width of cranidium, W1 - width of anterior lobe, W2 width (tr.) of occipital lobe, W3 - total width of palpebral area.

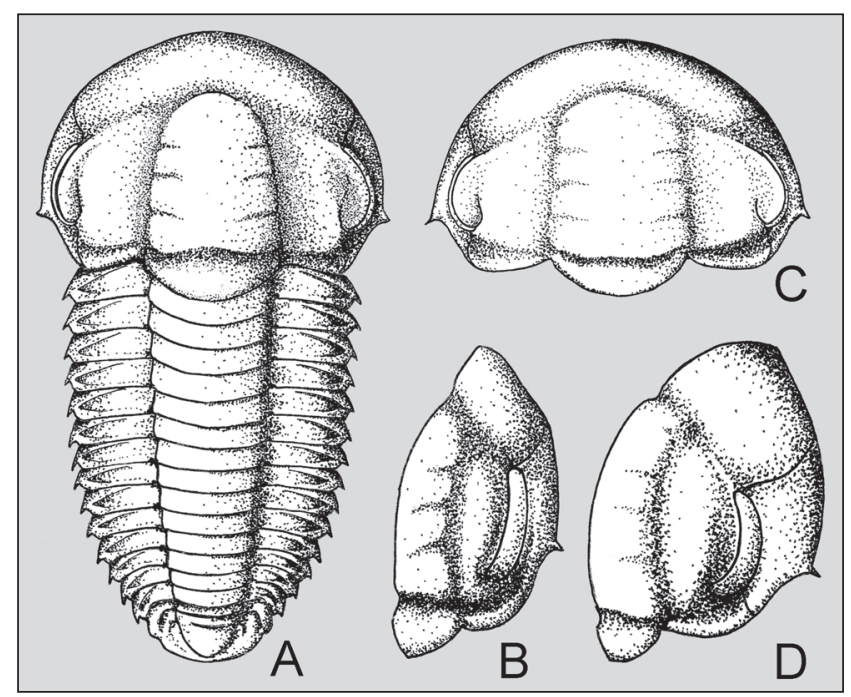

Figure 8. (A, B) Reconstructions of Ellipsocephalus linnarssoni in dorsal and lateral views. $(C, D)$ Cephalon of E. gripi in dorsal and lateral views; reflecting internal moulds.

\section{Genus Ellipsocephalus Zenker, 1833}

Type species: By monotypy (Zenker, 1833, p. 52), Trilobites Hoffi Schlotheim, 1823, p. 30, pl. 22, fig. 2, from the middle Cambrian Jince Formation (Ellipsocephalus hoffiLingulella-Rejkocephalus Assemblage Zone) near Jince (spelled Ginetz in older literature), Czech Republic.

Remarks: The diagnosis given by Geyer (1990, p. 333) is followed here. Additionally, the librigenae possess minute laterally placed genal spines in some holaspids and the exoskeleton is finely punctuated in several species. The genus is characterised by the high transverse convexity of the cephalon, the steeply down-flexed anterior area, a moderately long occipital ring, and by the shallow dorsal furrows, except for the commonly well-developed occipital and posterior furrows. Ellipsocephalus is straddling the lower - middle Cambrian boundary in Scandinavia.

\section{Ellipsocephalus linnarssoni (Kiær, 1917)}

Figs. 8A, B, 9A-O, 10A-S, 13A

1883 [Pars.] Ellipsocephalus Nordenskjöldi n. sp., Linnarsson, pl. 4, fig. 2 (not fig. 1).

1903 Ellipsocephalus Nordenskjöldi Linnarsson Wiman, p. 44.

1917 Strenuella linnarssoni n. sp., Kiær, pp. 38-41, pl. 4; figs. 5, 6; pl. 5, figs. 8-10 (pl. 5, fig.7, PMO $73162=$ sp. indet.).

1962 Strenuella linnarssoni Kiær - Kautsky, p.18, pl. 1, figs. 5.6.

1978 Proampyx cf. linnarssoni (Kiær) - Ahlberg \& Bergström, p. 28, pl. 3, fig. 9.

1978 Proampyx linnarssoni (Kiær) - Ahlberg \& Bergström, p. 28, pl. 3, fig. 10; pl. 4, fig.4.

1978 Ellipsocephalus cf. gripi (Kautsky) - Ahlberg \& Bergström, p. 16, pl. 1, fig. 9.

1981 Proampyx cf. linnarssoni (Kiær) - Bergström \& Ahlberg, fig. 12D-E.

1983 Proampyx? sp., Ahlberg \& Bergström, p. 242, fig. $1 \mathrm{~A}$.

1990 Ornamentaspis? linnarssoni (Kiær) - Geyer, p. 127, pl. 26, fig. 11.

2012 Ornamentaspis? linnarssoni (Kiær) - Cederström et al., fig. $6 \mathrm{~F}$.

Type specimen: Lectotype cranidium PMO 61373a, selected and figured by Ahlberg \& Bergström (1978, p. 28 , pl. 3, fig. 10), mostly exfoliated, probably from the lower limestone bed of the Evjevik Member at Tømten, Ringsaker. Previously figured by Kiær (1917, pl. 4, fig. 5), duplicated by Kautsky (1962, pl. 1, fig. 6) and refigured here in dorsal and lateral views and deskewed dorsal view with strained ellipse (Fig. 9A-C).

Material: Cranidia from the Kiær Collection: PMO 61373a (lectotype), PMO 61373b, on the same slab as the lectotype, PMO 73154, PMO 73163, PMO 73164 (all paralectotypes). PMO 73162, included in the series described by Kiær (1917, pl. 5, fig. 7), is not determinable and no longer conforms to the specimen figured by Kiær due to abrasion. Several fragmentary cranidia are found on a slab (PMO 98116) collected by G. Henningsmoen at Rena, east of Lake Mjøsa. New material figured herein: one cranidium with twelve attached thoracic segments, PMO 227.648, thirteen cranidia, PMO 227.633-PMO 227.645, four librigenae, PMO 227.649-PMO 227.652, three thoracic segments, PMO 227.641/2, PMO 227.646, PMO 227.647 and one pygidium, PMO 227.653. Additionally, almost two hundred more or less tectonically distorted cranidia, fifteen librigenae and two pygidia have been studied. 

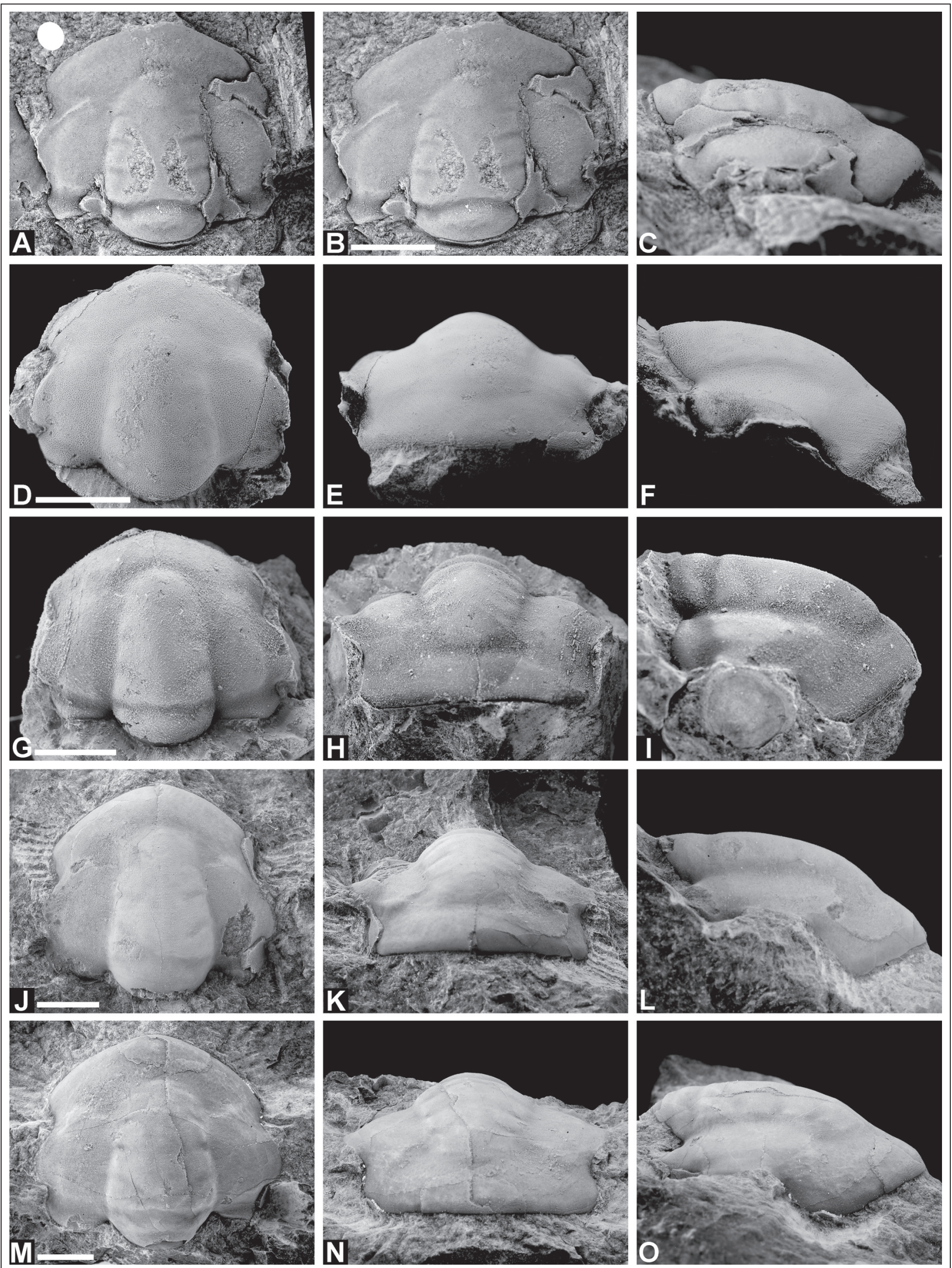

Figure 9. Ellipsocephalus linnarssoni (Kiwer, 1917). (A-C) Dorsal and lateral views of the lectotype cranidium, PMO 61373a, figured by Kioer (1917, pl. 4, fig. 5). Tømten Farm. A is retrodeformed with a strained ellipse. (D-F) Dorsal, frontal and lateral views of well-preserved cranidium, PMO 227.633, retaining the densely punctuated exoskeleton. Ringstrand. (G-I) Dorsal, frontal and lateral views of internal mould of a cranidium, PMO 227.634, laterally compressed. Lower bed, Skyberg Farm. (J-L) Dorsal, frontal and lateral views of a large, exfoliated cranidium, PMO 227.635, laterally compressed. Ringstrand. (M-O) Dorsal, frontal and lateral views of a large, exfoliated cranidium, PMO 227.636. Upper bed, Ringstrand. All scale bars: $5 \mathrm{~mm}$. 
Emended diagnosis: An Ellipsocephalus species with anterior cranidial margin widely parabolic. Glabella tapering. Palpebral lobes run from anteriorly on L3 to midway on L1. Palpebral area down sloping to palpebral lobe from very shallow dorsal furrow. Librigena with minute spine situated slightly behind midway on lateral margin. Thoracic segments without axial node or spine, pleural field and axis equal in width. Short pleural spines. Pygidium less than twice as wide as long, axis highly convex, almost extending to posterior margin. One axial ring, one to two pleural furrows. Entire exoskeleton densely pitted.

Description: Librigenae, thoracic segments and a pygidium are figured and described here for the first time and facilitates an emended description of the species. Exoskeleton comparatively thick, thicker along the furrows and finely punctuated on all segments. The cranidium is 1.1 to 1.2 times as wide as long, widest at the palpebral lobes and widely parabolic at anterior margin.

On internal moulds, the distinctly tapering glabella has three pairs of short lateral furrows. S1 is curved backwards adaxially, S2 less so and S3 nearly transverse. L1 and L2 are equally long (sag.), L3 slightly shorter, the frontal lobe being the longest and rounded anteriorly. Rare specimens have a fourth pair of very short and faint glabellar furrows (Figs. 9M, 10E). The transglabellar occipital furrow is wide (sag.), variably deep and usually anteriorly curved at the sagittal line. The occipital ring varies in length (sag.), and the Le1/Le2-ratio is approximately 0.4 . No occipital node or spine, the posterior margin is evenly rounded.

The axial furrows are very shallow, marked only by a change in slope from the glabella onto the fixigena. Some specimens tend to have weakly concave axial furrows. Preglabellar furrow widens laterally in front of the low eye ridges. Small cranidia have more pronounced dorsal furrows (Fig. 10B, C).

Eye ridges faint and obliquely directed, only visible on internal moulds and cut off by the dorsal furrow.

The ocular lobes range at a transverse line from anterior part of L3 to the posterior furrow, adjacent to the middle part of L1. The palpebral area is gently down-sloping to the palpebral lobes (Fig. 9E, H, K, N), although small cranidia less than $6 \mathrm{~mm}$ long have more horizontal palpebral areas.

The distinct posterior furrow widens laterally. The posterior margin runs straight laterally to the fulcrum where it bends angularly forwards. The anterior branches of the facial suture diverge forwards to opposite the middle part of the frontal lobe where they converge towards the sagittal line, outlining an anterior area of even sagittal length. In juvenile specimens less than $6 \mathrm{~mm}$ in length, the anterior facial sutures converge in front of the anterior glabellar lobe (Fig. 8B, D). No border furrow is present. When the exoskeleton is retained, furrows are hardly visible, except for the posterior furrows (Fig. 9D-F). Two to four, discontinuous terrace lines are running parallel close to the cephalic margin.
Librigena narrow and provided with a minute genal spine just behind midway on the lateral margin. Anterior lateral margin is evenly convex, the shorter posterior lateral margin slightly concave. Doublure less than half as wide as the librigena. During growth, the librigena narrows in length/width proportions (Fig. $10 \mathrm{O}, \mathrm{R}$ ).

The number of thoracic segments is unknown, but a truncated carapace lacking the posterior part has 12 segments (Fig. 10N). The axis and pleural field are about equal in width (tr.). The posterior margin of the pleural tips is directed obliquely forwards ending in a thorn-like, short pleural spine (Fig. 10J-L). A deep and wide pleural furrow narrows distally and terminates at the centre of the spine base, dividing the pleural region into equally long (sag.) posterior and anterior pleural bands. The articulating facet is distinctly set off on approximately half the frontal pleural band. A robust connecting half ring is divided from the axial ring by a deep furrow. An axial node or spine is absent on the thoracic segments.

Pygidium 1.7 times as wide as long with prominent axis occupying half of the total width. This very convex axis extends almost to the posterior margin and shows one to two axial rings and an end lobe. The pleural field is half as wide as the axis with one or two, strongly backwardly directed pleural furrows. A pair of bulges appears along the lateral margin at the end of the anterior pleural furrow.

Discussion: Geyer (1990, p. 127) reassigned several Scandinavian ellipsocephalid species to the new genus Ornamentaspis, with most species occurring in the middle Cambrian (provisional stage 5). Strenuella linnarssoni Kiær, was tentatively included, but the spine morphology is significantly different from the Ornamentaspis species figured by Geyer in lacking a strong occipital spine and coarse posterolateral genal spines. The species is further distinguished from Ornamentaspis by the higher cephalic convexity and the evenly down-sloping palpebral area from the very shallow dorsal furrow to the low palpebral lobes. A diagnostic feature in Ornamentaspis is the transversally convex palpebral area gently rising above the distinct axial and palpebral furrows. Ornamentaspis possesses deep palpebral furrows, a straight occipital furrow and the anterior area has a shallow border furrow, which is not seen in E. linnarssoni. Additionally, no parafrontal band or anterolateral corners on the frontal lobe possessing a faint connection to the eye ridges are developed in E. linnarssoni. According to Geyer (1990, p. 127), Ornamentaspis species were probably strongly micropygous, but E. linnarssoni is not. Therefore, the species is here excluded from Ornamentaspis.

The middle Cambrian genus Proampyx Frech, 1897, to which Ahlberg \& Bergström (1978) tentatively referred the species, is morphologically distinctly different from E. linnarssoni. Proampyx is assigned to the family Agraulidae (Geyer \& Landing, 2001; Fletcher et al., 2005; Álvaro et al., 2012; Weidner $\&$ Nielsen, 2015). The type species, Proampyx acuminatus (Angelin, 1851) from Andrarum, southern Sweden, and the associated congeneric species 

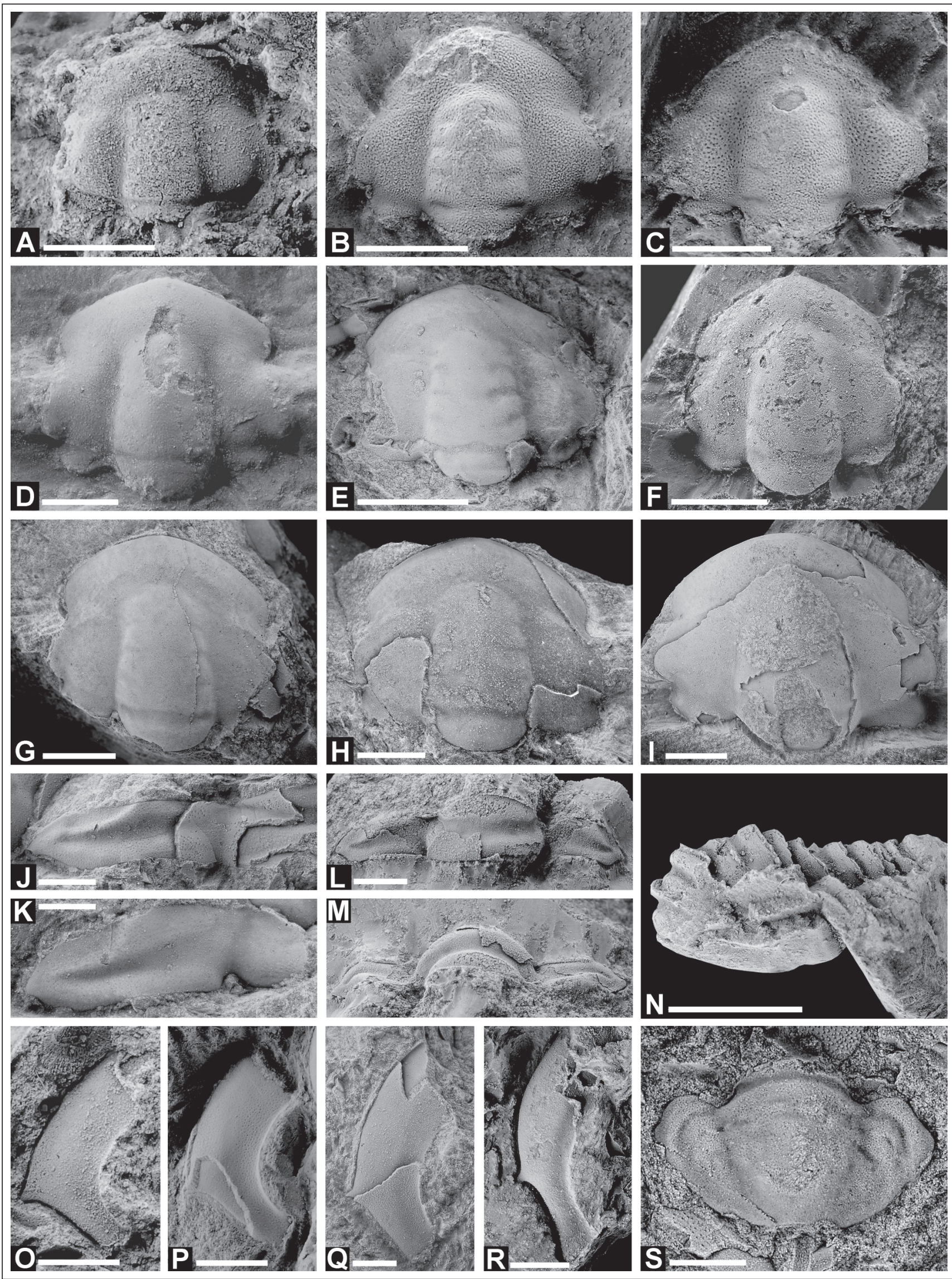
Figure 10. Ellipsocephalus linnarssoni (Kicer, 1917). ). (A) Internal mould of a meraspid cranidium, PMO 227.637. Lower bed, Skyberg Farm. (B) Meraspid cranidium, PMO 227.638, retaining the exoskeleton. Note the well-expressed furrows. Ringstrand. (C) Meraspid cranidium, $P M O$ 227.639, retaining the exoskeleton. Note the proportionally large punctuations. Ringstrand. (D) Small cranidium, PMO 227.640, retaining the exoskeleton, upper bed. Ringstrand. (E) Exfoliated cranidium, PMO 227.641/1, with well-expressed glabellar furrows. Ringstrand. (F) Internal mould of a laterally compressed cranidium, PMO 227.642. Skyberg Farm. (G) Exfoliated cranidium, PMO 227.643. Ringstrand. (H) Largely exfoliated cranidium, PMO 227.644. Ringstrand. (I) Largest cranidium at hand, PMO 227.645, $23.3 \mathrm{~mm}$ in width, retaining most of the exoskeleton. Ringstrand. (J) Thoracic segment, PMO 227.646, pitted exoskeleton partly preserved. Ringstrand. (K) Fragmental, thoracic segment, PMO 227.641/2, same slab as $E$. $(L, M)$ Dorsal and frontal view of thoracic segment, $P M O$ 227.647. Note the highly raised axis. Upper bed, Skyberg Farm. (N) Lateral view of cranidium with twelve attached thoracic segments, PMO 227.648, internal mould. Lower bed, Skyberg Farm. (O) Small librigena, PMO 227.649, internal mould. Lower bed, Skyberg Farm. (P) Small librigena, $P M O$ 227.650, retaining the pitted exoskeleton. Ringstrand. (Q) Librigena, PMO 227.651, showing the dobloure and minute genal spine. Upper bed, Ringstrand. (R) Large and comparatively narrow librigena, PMO 227.652. Upper bed, Skyberg Farm. (S) Pygidium retaining the pitted exoskeleton, $P M O$ 227.653. Ringstrand. Scale bars on A-D, J-M, O-S: $2 \mathrm{~mm}$. Scale bars on $E-I, N: 5 \mathrm{~mm}$.

(assigned to Agraulos by Westergård, 1953), all show a low convexity (sag. and tr.) of the cephalon. The shape and outline of the frontal and posterior areas are remarkably different from E. linnarssoni. Further, a truncated glabella with bigeniculate and geniculate lateral furrows and the presence of an occipital node or strong spine in Proampyx are clearly different from E. linnarssoni. Newly collected and complete specimens of Proampyx from the Lejopyge laevigata Zone, Norway, possess long posterolateral genal spines. The pleural field and the segmented pygidium are considerably wider than in E. linnarssoni. The species is here excluded from Proampyx, in accordance with Geyer et al. (2004, p. 128).

Kautsky (1962, p. 18) argued that Strenuella linnarssoni Kiær, 1917, was so similar to Strenuella (Ellipsostrenua) gripi (now Ellipsocephalus gripi) that it should be assigned to the same subgenus; this was not formally followed up in his figure captions of plates 3-5. Henningsmoen (1959) raised the subgenus to generic rank, but this was not mentioned by Kautsky (1962).

E. linnarssoni is very similar to Ellipsocephalus gripi, and occurs associated in the Mjøsa area, although the latter is uncommon. E. gripi has a markedly long and steeply down-sloping anterior area, LAA, which is usually $50 \%$ as long as the parameter Le2 (Fig. 7) seen in lateral view and followed along the sagittal convex curvature (see Figs. 5F, $8 \mathrm{D}, 11 \mathrm{~B}, \mathrm{E}, \mathrm{H}, \mathrm{K}, \mathrm{N})$. In E. linnarssoni the less steep anterior area is about $40 \%$ as long as Le2 (Figs. 8B, 9C, F, I, L, $\mathrm{O})$, resulting in a higher sagittal convexity of the cephalon in E. gripi. The glabella is distinctly tapering in E. linnarssoni, showing a W2/W1-ratio of approximately 1.3. In E. gripi the ratio is approximately 1.2 . Le1 is slightly shorter in E. gripi with an average Le1/Le2-ratio of 0.3 . Glabellar S1 and S2 tend to be less backwardly directed than seen in E. linnarssoni. Cephalic, thoracic and pygidial elements of E. linnarssoni have densely spaced pits, which are generally not observed in E. gripi. The preocular facial suture on the librigena is longer than in E. linnarssoni, otherwise the librigenae of the two species are very similar. Thoracic segments and pygidia of the two species seem indistinguishable in exfoliated material, although the pleural spines tend to be longer in E. gripi. Ahlberg \& Bergström (1978, pl. 1, fig. 9) figured a plaster cast of an external mould from Rena, east of the Mjøsa area, as Ellipsocephalus cf. gripi. This is here transferred to E. linnarssoni, based on a comparatively shorter anterior area. Several taxa figured from Sweden are here considered to fall within the intraspecific variation of E. linnarssoni (see synonymy list). Re-examination and preparation of a specimen in Kautsky's type series of E. gripi (Kautsky, 1945, plate 15, fig. 3) shows that E. linnarssoni is probably present among this material.

Occurrence: E. linnarssoni is previously reported from the Lower Allochthon Evjevik Member at Tømten (Kiær, 1917), Evjevika (Münster, 1900; Kiær, 1917), Ringstrand (Geyer, 1990), Østre Åbu, Rena (Ahlberg \& Bergström, 1978) and the river Finna in Snertingdalen (Münster, 1900). It is common in the lower bed and forming coquinas in the upper bed of the Evjevik Member at Skyberg. One specimen from Ustaoset (Størmer, 1925, pl.1, fig. 1) is very similar but cannot be assigned to the species with certainty.

In Sweden, the species is known from the Gislöv Formation, Gislövshammar, Scania (Bergström \& Ahlberg, 1981; Cederström et al., 2009), and reported from the uppermost part of the Gärdsjön Formation, Jämtland (Cederström et al., 2009). The species is also reported from the Grammajukku Formation at Mt Assjatj (Aistjakk) and Delliknäs in central Lapland, and from Jiltjaur, Tallträsk, Högland and Bergmyrhobben in southern Lapland (Cederström et al., 2012).

\section{Ellipsocephalus gripi (Kautsky, 1945)}

Figs. 5D-J, 8C, D, 11A-O, 13B

1917 Ellipsocephalus Nordenskjöldi Linnarsson - Kiær, pp. 41-44, pl. 5, fig. 13 (not pl. 4, figs. 7, 8; pl. 5, figs. $11,12=$ sp. indet.).

1978 Ellipsocephalus gripi (Kautsky) - Ahlberg \& Bergström, pp. $15-17$, pl. 1, figs. $6,7,10$ (fig. $8=$ sp. indet. fig. $9=$ E. linnarssoni).

1979 Ellipsocephalus cf. gripi (Kautsky) - Ahlberg, pp. 8-9, fig. $3 \mathrm{H}$.

1980 Ellipsocephalus cf. gripi (Kautsky) - Ahlberg, pp.156-158, fig. 3C.

2012 Ellipsocephalus gripi (Kautsky) - Cederström et al., fig. $6 \mathrm{G}$.

See Ahlberg \& Bergström (1978) for further synonyms.

Type specimen: Lectotype cephalon with eight thoracic segments attached NRM Ar9034, selected by Ahlberg \& Bergström (1978, p. 16). From the Grammajukku Formation at Mt Assjatj, Laisvall, Swedish central Lapland. 

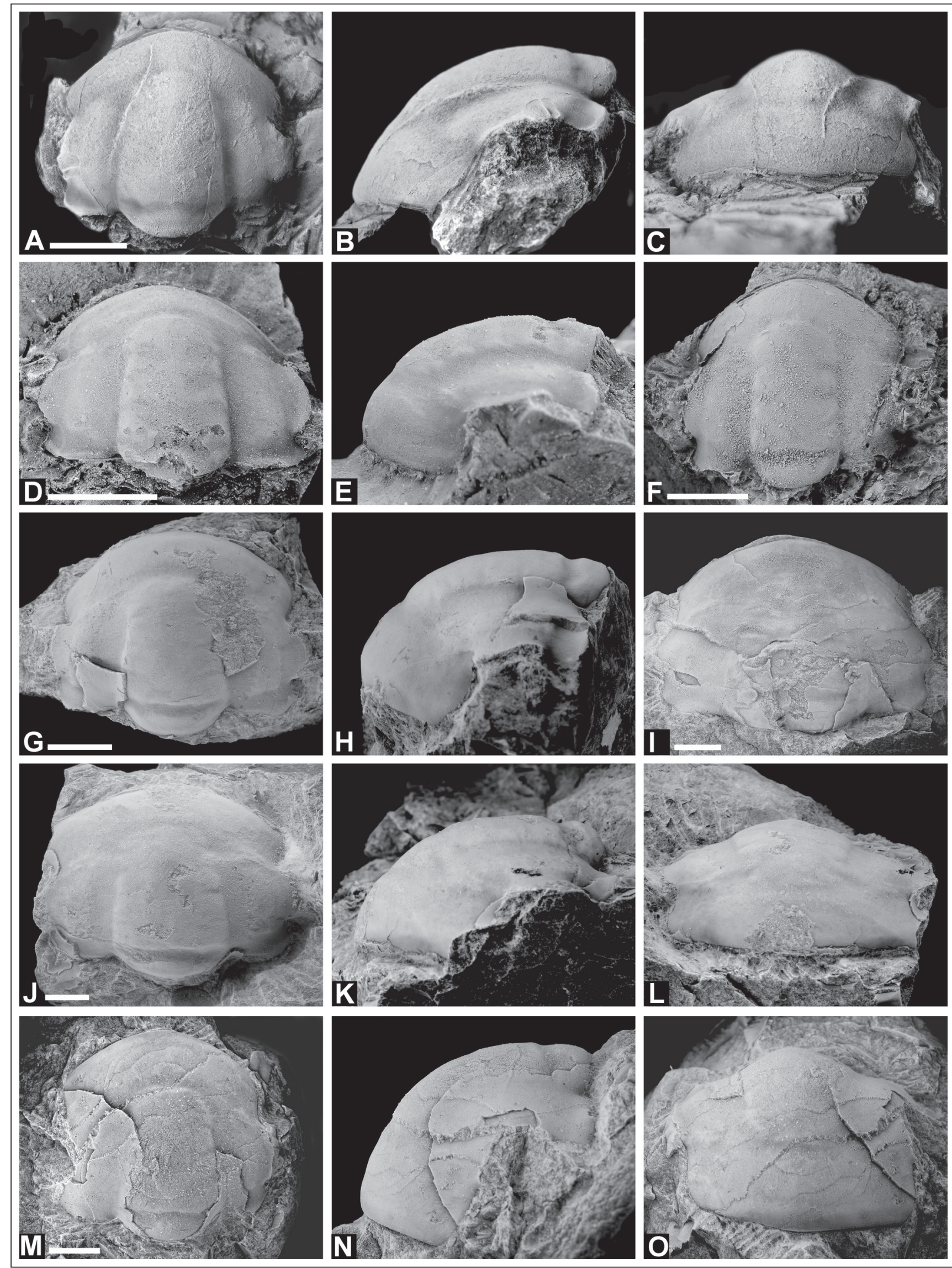
Figure 11. Ellipsocephalus gripi (Kautsky, 1945): (A-C) Dorsal, lateral and anterior views of cranidium, Ar 9031, Kautsky's type material (1945, pl. 15.8). Mt. Assjatj, Sweden. (D, E) Dorsal and lateral views of internal mould of cranidium, PMO 227.654. Upper bed, Skyberg Farm. (F) Internal mould of laterally compressed cranidium, PMO 227.655. Skyberg Farm. (G, H) Dorsal and lateral views of large, mostly exfoliated cranidium, PMO 227.656. Note thickness of the test. (I) Largest cranidium at hand, PMO 227.657, $30 \mathrm{~mm}$ in width. Ringstrand. Note the very shallow furrows. (J-L) Dorsal, lateral and frontal views of very large exfoliated cranidium, PMO 227.658 , with shallow furrows and short occipital ring. Ringstrand. $(M-O)$ Dorsal, lateral and frontal views of largely exfoliated cranidium, PMO 227.659, with very long anterior area. Ringstrand. All scale bars: $5 \mathrm{~mm}$.

Figured by Kautsky (1945, pl. 14, fig. 7; 1962, pl. 1, fig. 2). Several specimens from Kautsky's type series are refigured herein (Fig. 5D-K, 11A-C).

Material: From the Kiær Collection: cranidium PMO 73165 from Tømten. New material: Seven cranidia, PMO 227.654-PMO 227.660 from the Evjevik Member at Skyberg and Ringstrand.

Discussion: Ellipsocephalus gripi is a well-known lower Cambrian ellipsocephalid species with a number of fairly well preserved specimens of different ontogenetic stages described and figured in several papers (Kautsky, 1945, 1962; Ahlberg \& Bergström, 1978). The species is strikingly similar to E. linnarssoni, and is separated mainly by the very long and steeply down-sloping anterior area in E. gripi (for remarks on separating features, see discussion of E. linnarssoni above).

Examination of the type series of Kautsky (1945) proved that E. gripi have minute punctuation on the glabellar exoskeleton, as seen in cranidia from the Evjevik Member (Fig. 13B). E. linnarssoni seems to be present among Kautsky's material (Kautsky, pl. 15, fig. 3), and scattered granulation on two specimens (Kautsky, 1945, pl. 13, figs. 9, 12) is similar to O.? sularpensis or O.? granulatus (Ahlberg, 1984).

Ahlberg \& Bergström (1978, p. 16) questionably assigned all specimens of Ellipsocephalus nordenskjoeldi figured by Kiær (1917, pl. 4, figs. 7, 8; pl. 5, figs. 1-13) to E. gripi. The specimens have been re-examined but were found to be too weathered or tectonically distorted to be determined at species level, except for the well-preserved specimen in Kiær's pl. 5, fig. 13 (PMO 73165). E. gripi is co-occurring with E. linnarssoni in the Grammajukku Formation at $\mathrm{Mt}$ Assjatj and Delliknäs in central Lapland and Jiltjaur, Tallträsk, Högland and Bergmyrhobben in southern Lapland and in the Gärdsjön Formation at Fånån in Jämtland. It is absent in Scania, southern Sweden.

Occurrence: In Norway, E. gripi is recorded from the Lower Allochthon Evjevik Member, Mjøsa area, at Tømten, Ringstrand and Skyberg. In Sweden, the species is known from the Grammajukku and Gärdsjön formations at several localities along the Caledonian front.
Genus Ornamentaspis Geyer, 1990

Type species: By original designation, Ornamentaspis frequens Geyer, 1990, p. 128, pl. 24, fig. 22 from the Ornamentaspis frequens Zone in Jbel Wawrmast Formation in the High Atlas, Morocco.

Remarks: The genus is characterised by the transversely convex palpebral area rising above the distinct dorsal furrows.

Ornamentaspis? sularpensis (Ahlberg \& Bergström, 1978) Figs. 12A-N, 13C

1917 [Pars.] Strenuella primaeva Brøgger - Kiær, pl. 4, figs. $1,2$.

1978 Proampyx sularpensis n. sp., Ahlberg \& Bergström, pp. 25-26, pl. 3, fig. 6: pl. 4, fig. 5.

1978 Proampyx cf. sularpensis Ahlberg \& Bergström Ahlberg \& Bergström, pp. 26-27, pl. 3, fig. 5.

1990 Ornamentaspis sularpensis (Ahlberg \& Bergström) - Geyer, p. 127.

2010 Proampyx? sularpensis Ahlberg \& Bergström Cederström et al., text-fig. 11E.

2012 Proampyx? sularpensis Ahlberg \& Bergström Cederström et al., text-fig. 8B-C.

Type specimen: Holotype cranidium LO 5334, figured by Ahlberg \& Bergström (1978, pl. 3, fig. 6). From the Gislöv Formation at Hardeberga, Scania, southern Sweden.

Material: Six cranidia, PMO 227.641/3, PMO 227.661PMO 227.665; one thoracic segment, PMO 227.667 and one pygidium, PMO 227.666. All specimens are from the Evjevik Member at Ringstrand.

Description of the Norwegian material: The species is small with a cranidial length less than $8 \mathrm{~mm}$ and characterised by the minute granules that cover the surface on the entire exoskeleton. Internal moulds are finely pitted, corresponding to the granules on the exoskeletal surface. The exoskeleton is thick. The dorsal furrows are wide and distinct on specimens retaining the exoskeleton.

Glabella tapering with three glabellar furrows posteriorly curved and about equally long. Some internal moulds (Fig. 12J) show a fourth pair of lateral furrows, delimiting a fourth pair of short lobes, L4. The Le1/W2-ratio is approximately 0.4 .

Palpebral area convex and slightly raised above the axial furrow and the deep palpebral furrow. The palpebral lobes are long and extend from a level adjacent to the posterior part of the frontal lobe and back to the midway on L1. Eye ridges distinct, but cut off by the dorsal furrow and they do not merge with the glabella.

The anterior facial sutures diverge forward to opposite the anteriormost part of the frontal lobe. Here, the sutures sharply converge towards the sagittal line, outlining an anterior area of even length (sag. and exsag.). The anterior area is convex and steeply down sloping. 
Some internal moulds have a faint anterior border indicated anterolaterally (Fig. 12B, C, J).

The number of thoracic segments is unknown. Transversally, the thorax is rather convex with a highly raised axis. Small and densely spaced granules cover the segments except along the furrows (Fig. 12N). The pleural field is about as wide as the axis, with a short and broad based pleural spine. The pleural furrow is wide adaxially, narrowing laterally, and terminates at the posterior margin of the pleural spine. The anterior pleural band is longer (sag.) than the posterior band. The ring furrow is long (sag.) and deep across the axis.

Pygidium previously unknown. One pygidium (PMO 227.666, Fig. 12M) retaining the exoskeleton is here assigned to the species due to the characteristic granulation. It is nearly 1.5 times as wide as long and the highly convex axis is more than 3 times as wide as the pleural field. Distinct segmentation is not seen on the axis in this testaceous specimen. A short postaxial field is present. One shallow pleural furrow is directed strongly backwards. The anterior pleural margins are bent almost straight backwards with an angle at the fulcrum.

Discussion: Small specimens with a granulated exoskeleton are here questionably assigned to O.? sularpensis (Ahlberg \& Bergström, 1978), a species previously placed with Proampyx and recorded only from the Gislöv Formation, Scania, southern Sweden (Ahlberg \& Bergström, 1978; Bergström \& Ahlberg, 1981). The Norwegian material agrees well with the description of Proampyx sularpensis given by Ahlberg \& Bergström (1978, pp. 25-26) and numerous new and well-preserved specimens collected at the type locality at Gislövshammar, Scania, southern Sweden (P. Cederström's coll.). As discussed above (see discussion of Ellipsocephalus linnarssoni) the generic features of Proampyx is obviously different from the present taxon as well. Geyer (1990, p. 127) assigned the species to Ornamentaspis. The convex palpebral area, the relatively low transverse convexity of the cranidium, the dorsal furrows and an anterior border furrow in some specimens of O.? sularpensis are all characteristic Ornamentaspis features, but the spine morphology is distinctly different (see Cederström et al., 2010, text-fig. 11E) and the species is here tentatively assigned to Ornamentaspis.

The well-impressed preglabellar furrow and the comparatively convex glabella with distinct furrows led Kiær (1917, p. 33, pl. 4, figs. 1, 2) to describe some small cranidia from a loose boulder of sandy limestone as nonflattened specimens of Strenuaeva primaeva. These specimens (PMO 73152, PMO 22862) are re-examined and despite the very poor preservation, the characteristic convex palpebral area and the proportionally larger glabella are preserved and they are here referred to O.? sularpensis. S. primaeva is separated from O.? sularpensis by the long occipital ring, narrow glabella, transverse eye ridges, the much wider palpebral areas and a large and swollen anterior area. S. primaeva also seems to be stratigraphically older, hitherto only found with certainty
Figure 12. (A-N) Ornamentaspis? sularpensis (Ahlberg \& Bergström, 1978). (A) Cranidium, PMO 227.641/3 (same slab as Fig. 10E, K) with parts of granulated exoskeleton preserved. Ringstrand. (B) Cranidium, PMO 227.661. Ringstrand. (C) Exfoliated cranidium, PMO 227.662, with anterior border furrow. Ringstrand. (D-F) Dorsal, oblique antero-lateral and lateral views of cranidium retaining the exoskeleton, PMO 227.663. Upper bed, Ringstrand. $(G-I)$ Dorsal, frontal and oblique antero-lateral views of exfoliated and laterally compressed cranidium, PMO 227.664. Ringstrand. (J-L) Dorsal, frontal and lateral views of large, tectonically skewed cranidium, PMO 227.665. Note short L4 and anterior border furrow. Ringstrand. (M) Pygidium, PMO 227.666, retaining the granulated exoskeleton. Upper bed, Ringstrand. (N) Fragmental thoracic segment, PMO 227.667, with part of granulated exoskeleton preserved. Upper bed, Ringstrand. (O) Gen. et sp. A. Internal mould of cranidium, PMO 227.668, with rapidly narrowing glabella. Upper bed, Skyberg Farm. All scale bars: $2 \mathrm{~mm}$.

in the green mudstone of the Tømten Member. Among Kautsky's (1945) type series of E. gripi, there are two unfigured cranidia (on the same slab as NMR Ar9031 and NMR Ar9033) resembling O.? sularpensis. O.? sularpensis is very similar to Strenuaeva? kullingi Ahlberg \& Bergström, 1978 and a future revision of Strenuaeva is needed to clarify the generic assignment of the present taxon.

Occurrence: Lower Allochthon Evjevik Member at Tømten, Ringstrand and Skyberg in the Mjøsa area, Norway. Originally described from the Gislöv Formation at Hardeberga and also reported from Gislövshammar in Scania, southern Sweden.

\section{Genus Strenuaeva Richter \& Richter, 1940}

Type species: By original designation, Arionellus primeevus Brøgger, 1878, p. 58, from the lower Cambrian provisional series 2, stage 4, Tømten Member of the Ringstrand Formation at Tømten Farm in Ringsaker, Mjøsa area, Norway.

Remarks: The cephalon is characterised by a deep axial furrow and a wide and distinct transverse furrow in front of the glabella and ocular ridges. The long (sag.) anterior area and interocular areas are convex. The occipital ring is comparatively long (sag.). Several lower Cambrian species of Strenuaeva have been described from Sweden (see Ahlberg \& Bergström 1978).

\section{Strenuaeva spinosa Ahlberg \& Bergström, 1978}

Fig. 13G-I

2012 Strenuaeva spinosa Ahlberg \& Bergström - Cederström et al., figs. 10-13, 15A-X, 16, 17.

See Cederström et al. (2012) for further synonyms.

Type specimen: Holotype cranidium SGU Type 8, selected and figured by Ahlberg \& Bergström (1978, pl. 

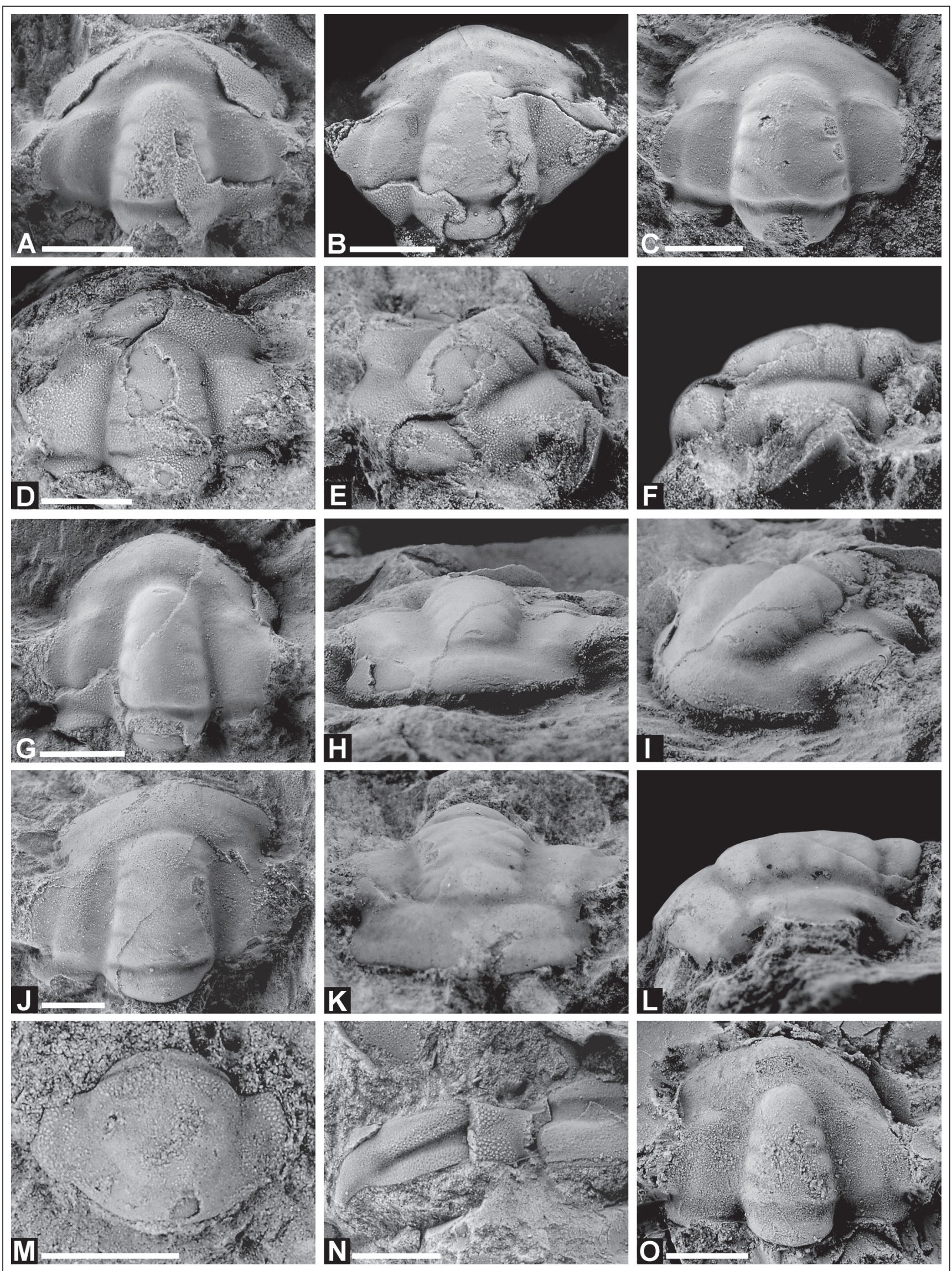
2, fig. 4). Loose boulder deriving from grey ' $k j e r u l f i$-shale' near Laisvall, central Swedish Lapland.

Material: One partly preserved cranidium, PMO 223.406, recently figured by Cederström et al. (2012, fig. $12 \mathrm{~F}, \mathrm{~L})$ from Ringstrand. New material: one poorly preserved cranidium, PMO 227.670 from the mudstone bed of the Evjevik Member at Skyberg.

Remarks: In his revision of Moroccan ellipsocephalid taxa, Geyer (1990) established the new genus Issafeniella that in several features is similar to Strenuaeva. The genus was based on cranidial material only. Separating characters are the long occipital spine and the comparatively wider glabella seen in Issafeniella. Although we tentatively follow Ahlberg \& Bergström (1978) and Cederström et al. (2012) and retain the species in Strenuaeva, descriptions of librigenal and postcephalic material of Issafeniella may change the generic assignment.

Strenuaeva spinosa is easily distinguished from co-occurring ellipsocephalids by the prominent spinosity. The cranidium is characterised by a long occipital spine and the anterior area is less convex and down sloping compared to co-occurring ellipsocephalids.

Occurrence: The Lower Allochthon Evjevik Member, in the upper part of the mudstone bed at Skyberg and in the upper limestone bed at Ringstrand, Mjøsa area, Norway. From Sweden, Cederström et al. (2012) reported S. spinosa from the lower part of the Ornamentaspis? linnarssoni Zone, Gislöv Formation in Scania, southern Sweden and in the Grammajukku Formation from a series of localities along the Caledonian front.

\section{Gen. et sp. indet. A}

Fig. $12 \mathrm{O}$

Material: Two internal cranidial moulds (PMO 227.668, PMO 227.674), $5 \mathrm{~mm}$ long, collected from the upper limestone bed of the Evjevik Member at Skyberg. The most complete cranidium is figured.

Description: The glabella is narrow (tr.) and rapidly tapering with a very narrow anterior lobe. The glabellar lobes are distinctly set off by well impressed glabellar furrows; the occipital furrow is straight across the glabella and of even depth and sagittal length. The palpebral area is horizontal.

Discussion: The specimens show greatest resemblance to Ornamentaspis? sularpensis, having a horizontal palpebral area, but the glabella is proportionally narrower and considerably more tapering. Further, the occipital furrow is slightly different. This might be caused by tectonic distortion, although the palpebral areas seem undistorted. The taxon also shares some similarities with the genus Berabichia Geyer, 1990 regarding the rapidly tapering glabella with distinct glabellar furrows. More material is needed to clarify the taxonomic affinity of this species.
Figure 13. (A) Ellipsocephalus linnarssoni (Kioer, 1917), close-up of cranidium, PMO 227.633, showing the densely punctuated exoskeleton. Same as Fig. 9D-F. (B) Ellipsocephalus gripi (Kautsky, 1945), close-up of cranidium retaining the exoskeleton, with scattered minute pits on the glabella. PMO 227.660. Upper bed, Ringstrand. (C) Ornamentaspis? sularpensis (Ahlberg \& Bergström, 1978), close-up of cranidium, PMO 227.661, showing partly preserved densely granulated exoskeleton. Same as Fig. 12B. (D-F) Gen. et sp. indet. B. Dorsal, frontal and lateral views of partly preserved cranidium, PMO 227.669. Note highly raised glabella and anterior border. Upper bed, Ringstrand. (G-I) Strenuaeva spinosa Ahlberg \& Bergström, 1978. ( $G, H)$ Dorsal and lateral views of partly preserved cranidium, PMO 223.406, retaining part of the exoskeleton. Upper bed, Ringstrand. (I) Poorly preserved and tectonically skewed internal mould of cranidium, PMO 227.670. Mudstone bed, Evjevik Member, Skyberg Farm. (J-L) Ellipsocephalus $c f$. lunatus Bergström \& Ahlberg, 1981. (J) Small cranidium, PMO 227.671, with distinct eye ridges and anterior border furrow. (K) Cranidium, PMO 227.672. (L) Cranidium, PMO 227.673. J-L are all internal moulds from the Skyberg Member at Skyberg Farm. (M-Q) Calodiscus lobatus (Hall, 1847). (M) Latex cast of external mould of small cranidium, PMO 227.675. ( $N, O)$ Dorsal and frontal views of poorly preserved cranidium lacking posterior part, PMO 227.676, internal mould. $(P, Q)$ Posterior and dorsal views of pygidium. Silicon cast of external mould, PMO 227.677. M-Q are all from the upper bed, Evjevik Member, Skyberg Farm. Scale bars on A-L: $2 \mathrm{~mm}$. Scale bars on $M-Q: 1 \mathrm{~mm}$.

\section{Gen.et sp. indet. B}

Fig. 13D-F

Material: One partly preserved ellipsocephalid cranidium PMO 227.669, $11 \mathrm{~mm}$ long, largely exfoliated with lateral parts of the fixigenae and anterior facial sutures not preserved. Collected from a loose boulder at Ringstrand, probably deriving from the upper limestone bed in the Evjevik Member based on the associated fossil content.

Description: Granules of different size cover the external surface and the internal mould is finely pitted. The exoskeleton is comparatively thin. The prominent glabella is moderately tapering, highly raised and evenly convex (tr.) with a rounded anterior lobe. The occipital furrow is distinct, also where the test is retained, and weakly curved anteriorly at the sagittal line. Le1/Le2-ratio is 0.35 and LAA is approximately $40 \%$ as long as Le2. No axial spine or node is present. Three pairs of shallow lateral furrows are present on the internal mould, S1 very wide, comparatively short and directed backwards. S2 shorter and transversally directed, while the faintly discernible and short S3 is anteriorly directed. The glabella is outlined by well-defined furrows on the internal mould. The convex anterior area is steeply down-sloping to a narrow (sag.) anterior border provided with 5-6 terrace lines running parallel to the margin. A palpebral furrow is indicated on the left fixigena (Fig. 13E), whereas the palpebral area is approximately half as wide as the glabella. The palpebral area is weakly convex and down-sloping to the palpebral furrow. Very low eye ridges, visible only in oblique light, are present on the internal mould. 


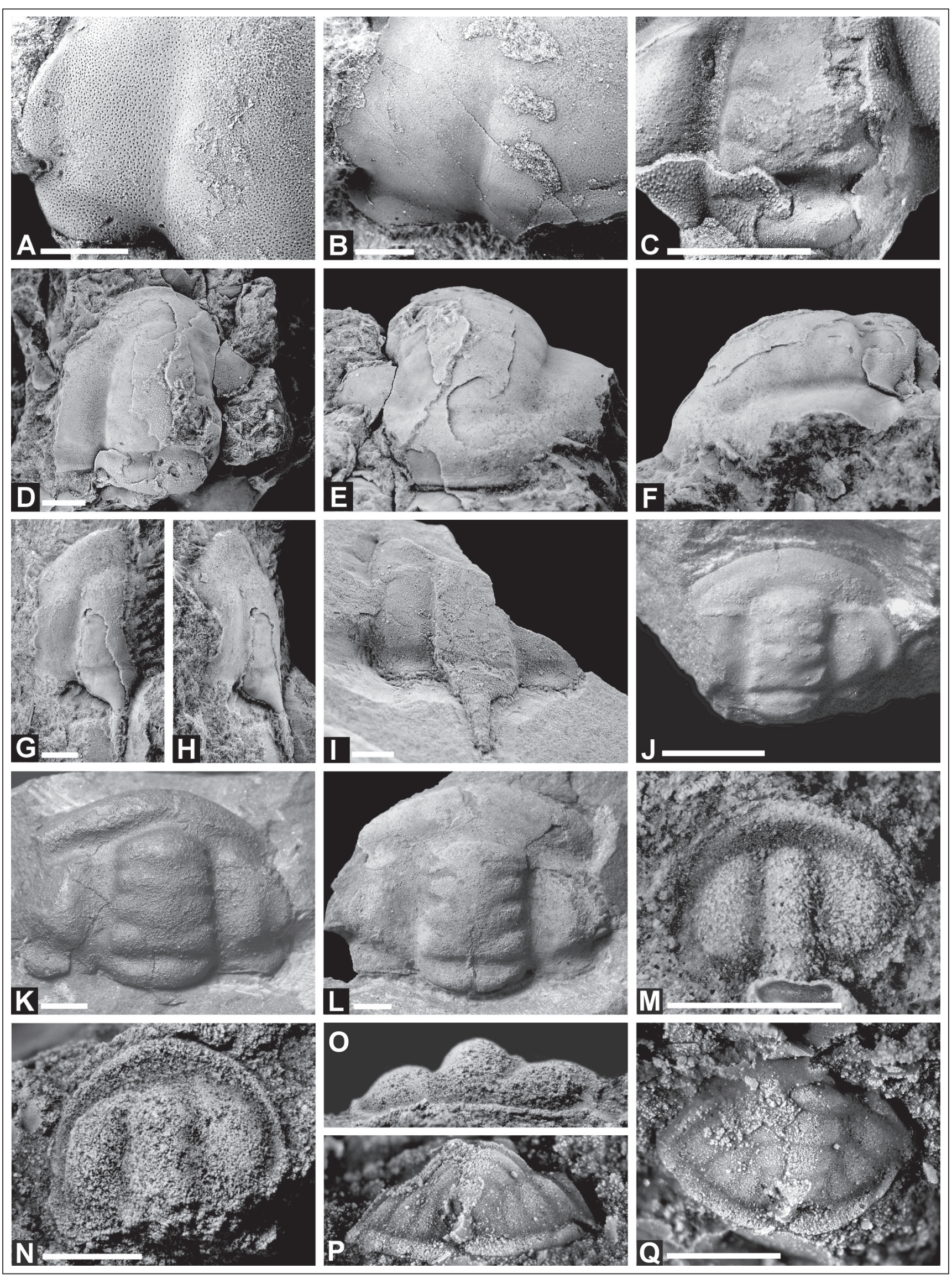


Discussion: The specimen differs from co-occurring ellipsocephalids by the comparatively larger and highly raised glabella with wide glabellar furrows and narrow palpebral area, W3. The anterior border is narrower than seen in O.? sularpenis and the test is comparatively thin. Despite its significant characters, more material is needed for clarifying identification.

\section{Superfamily Eodiscoidea Raymond, 1913}

Remarks: Eodiscoids are extremely rare in the Cambrian of Norway, and only two species have previously been described and figured from middle Cambrian strata (Høyberget \& Bruton, 2008). From lower Cambrian strata, only one possible pygidium from the Tømten Member at Tømten Farm has been recognised as Weymouthia nobilis by Kiær (1917, pl. 3, fig. 12 and 12a, b) and redescribed as Runcinodiscus cf. index by Ahlberg (1983b, p. 289). During recent investigations, a few poorly preserved specimens of Calodiscus lobatus (Hall, 1847) were collected from the Evjevik Member at Tømten and Skyberg. The species is figured herein for the first time from Norway.

\section{Family Calodiscidae Kobayashi, 1943}

Remarks: Three calodiscid taxa have been recognised from Scandinavian lower Cambrian strata: Neocobboldia aff. dentata (Lermontova, 1940) and Chelediscus acifer Rushton, 1966 were recorded from northern Sweden (Axheimer et al., 2007) whereas Calodiscus lobatus occurs abundantly in central and southern Sweden (Ahlberg, 1984; Bergström \& Ahlberg, 1981; Ahlberg \& Bergström, 1993; Cederström et al., 2009).

\section{Genus Calodiscus Howell, 1935}

Type species: By original designation of Howell (1935, p. 224), Agnostus lobatus Hall, 1847, p. 258, pl. 67, fig. 5a-f, from the upper part of the lower Cambrian Browns Pond Formation, Taconic region, New York State, USA.

\section{Calodiscus lobatus (Hall, 1847)}

Fig. 13M-Q

1987 Calodiscus lobatus (Hall) - Hinz, pp. 57-58, pl. 7, figs. 14-16, 18, 19.

1993 Calodiscus lobatus (Hall) -Ahlberg \& Bergström, pp. 331-334, fig. 1.

2009 Calodiscus lobatus (Hall) - Cederström et al., pp. 491-539, text figs. 8, 9, 11, 12, 15-18, 21, 22. pls. 1-12.

See these references for further synonyms.

Material: Two cephala (PMO 227.675, PMO 227.676, Fig. 13M-O) and two pygidia (PMO 227.677, Fig. 13P, $\mathrm{Q}, \mathrm{PMO}$ 227.678), internal and external moulds from the upper limestone bed of the Evjevik Member at Skyberg.
Remarks: The morphology, ontogeny and enrolment of Calodiscus lobatus is well known through the recent work of Cederström et al. (2009). The species is characterised by the semicircular cephalon and the highly convex glabella (tr.). No node or spine is present on the welldefined occipital ring, and the glabellar lateral furrows are deeply incised. No eyes are developed but low ocular ridges are present. Cederström et al. (2009) found the Swedish holaspid material to be morphologically very homogenous.

Calodiscus lobatus is widely distributed in the North Atlantic region, Europe, Morocco and Siberia and is particularly well known from Sweden. The species appears to be stratigraphically short ranging in the upper lower Cambrian in Scandinavia. Further attention should be paid to its stratigraphic significance worldwide.

Phylum Mollusca Cuvier, 1797

Class Helcionelloida Peel, 1991

Family Helcionellidae Wenz, 1938

Remarks: Few lower and middle Cambrian helcionelloid molluscs are known from Scandinavia. An unidentified specimen figured by Brøgger (1878) from the middle Cambrian of the Oslo Region, Norway, was later identified as Pelagiella kreklingensis Kobayashi, 1939. Specimens of Scenella barrandei (Linnarsson, 1879) are described from the Exsulans Limestone and coeval strata at Kiviks Esperöd in Scania, southern Sweden (Linnarsson, 1879), Lake Mjøsa, Norway (Strand, 1929) and on Bornholm, Denmark (Berg-Madsen \& Peel, 1986). Wiman (1903) described Stenotheca cornu Wiman, Stenotheca sp., and Scenella? sp. from drift material in Uppland, Sweden and the island of Åland, Finland. Bengtson (1980) assigned S. cornu to Lapworthella Cobbold, a member of a non-molluscan group referred to the tommotiids, while the validity of the two other Wiman taxa is unresolved. Kiær (1917) described 4 taxa from the Strenuella Limestone (Evjevik Member) at Tømten in Ringsaker, Norway, although three of the taxa are here considered conspecific. Kautsky (1945) described ?Scenella sp. and Helcionella rugosa Hall var. lapponica from Mt Assjatj in Swedish Lapland. From southern Sweden, Bergström \& Ahlberg (1981, fig. 14B) figured a specimen of Helcionella? sp. from the Holmia kjerulfi Zone at Kvasa near Simirishamn and reported occurrences from the same stratigraphical interval at Hardeberga and Gislövshammar. Peel \& Yochelson (1987) and Gubanov \& Peel (1999) redescribed Oelandia pauciplicata Westergård, 1936 from the middle Cambrian of Sweden. Mid Cambrian helcionelloids from the so-called 'Kalby Clay' (weathered Exsulans Limestone) and Andrarum Limestone of Bornholm, Denmark, were described by Grönwall (1902), Berg-Madsen \& Peel $(1978,1987)$ and Berg-Madsen (1985). Buchholz (2010, pl. 8, figs. 1, 2) figured a specimen of Scenella sp. found in drift material on Rügen, Germany, stemming from the Andrarum Limestone of Bornholm. Recently, a diverse and abundant fauna of helcionelloid molluscs, coeval with the presently described material from the Mjøsa area, was reported from 
the Gislöv Formation at Gislövshammar in Scania, southern Sweden (Ebbestad et al., 2009). That material derives from a $40 \mathrm{~cm}$-thick interval of laminated siltstone with intercalated calcareous nodules. Another but undescribed fauna has been reported from approximately the same stratigraphic level in Swedish Lapland by Cederström et al. (2014). The Skyberg fauna appears to be taxonomically identical to the Gislöv fauna, but has lower diversity (J.O.R. Ebbestad personal observation).

Parkhaev (2002) placed Helcionelloidea in a new subclass, Archaeobranchia, of the Class Gastropoda. Skovsted (2004) argued that suprageneric classification at our present level of knowledge of helcionelloids is likely to be arbitrary. As the material presented here does not add new data to the discussion of higher phylogeny of this group, the systematic of Parkhaev (2002) is not adopted here. Hence, Helcionellioida is treated in the original sense of Peel (1991a), followed by Geyer (1994), as representing endogastrically coiled, untorted molluscs (see Landing \& Bartowski, 1996, p. 752 for an alternative view).

\section{Genus Helcionella Grabau \& Shimer, 1909}

Type species: By original designation of Grabau \& Shimer (1909, pp. 607), Metoptoma? rugosa Hall, 1847, p. 306, pl. 83, fig. 6, from the lower Cambrian near Troy, New York State, USA.

Remarks: Grabau \& Shimer (1909) erected Helcionella with $H$. rugosa (Hall, 1847) as type species. That name was later suppressed because of homonymy and $H$. subrugosa (d'Orbigny, 1850) replaced Hall's name (see Knight, 1941, p. 142). Hall's species still remains the type species, in accordance with the International Commission on Zoological Nomenclature (1999) Article 67.1.2. "The name of a type species remains unchanged even when it is a junior synonym or homonym, or a suppressed name."

\section{Helcionella antiqua (Kiær, 1917)}

Fig. 14A-L

1917 Scenella antiqua n. sp., Kiær, p. 17, pl. 2, fig. 1.

1917 Scenella depressa n. sp., Kiær, p. 17, pl. 2, fig. 2.

1917 Helcionella cf. rugosa Hall - Kiær, p. 17, pl. 2, fig. 3.

1921 Scenella antiqua Kiær - Cobbold, p. 364.

1921 Scenella depressa Kiær - Cobbold, p. 364.

1938 Helcionella kiaeri n. sp., Resser, p. 14.

1945 ?Scenella sp., Kautsky, p. 147, pl. 11, fig. 2.

1945 Helcionella rugosa Hall var. lapponica nov var., Kautsky, p. 147, pl. 11, fig. 3.

1975 Scenella antiqua Kiær - Öpik, p. 37.

1976 [Non] Helcionella? antiqua n. sp., Abaimova, p. 174, pl. 20, figs. 1-15 (= Purella).

1986 Scenella depressa Kiær - Shergold \& Brasier, p. 299.

1986 Marocella depressa (Kiær) - Geyer, p. 96.

1986 Marocella antiqua (Kiær) - Geyer, p. 97.

2000 Scenella antiqua Kiær - Gubanov \& Peel, p. 143.

Type specimen: Holotype, by monotypy, PMO 73172 described and figured by Kiær (1917, p. 17, pl. 2, fig. 1).
The holotype, preserved in the brownish, soft decalcified rock of these strata, is now heavily abraded (refigured in Fig. 14A). From the Evjevik Member at Tømten Farm in Ringsaker, Mjøsa area, Norway. Probably from the lower bed.

Material: Specimens from Tømten: PMO 22892, the type specimen of Scenella depressa Kiær, 1917 (p. 17, pl. 2, fig. 2); PMO 24190, an external mould labelled as S. antiqua and stored with Kiær's holotype of the species (not figured by Kiær, 1917). PMO 24416, a badly worn specimen, which is the original of Helcionella cf. rugosa figured by Kiær (1917, pl. 2, fig. 3). New material from the lower and upper beds of the Evjevik Member at Skyberg Farm: PMO 227.682-PMO 277.685. One specimen from the Evjevik Member at Ringstrand (PMO 227.684).

Description: Shell patelliform, about 1.2 to 1.5 times longer than wide. The largest Norwegian specimen is $\sim 1.2$ $\mathrm{cm}$ long, but incomplete. Height of shell is about $0.4-$ 0.5 times the length. Apex at posterior 1/5 of the length. Shape of aperture elongated, almost parallel sided with more rounded anterior and posterior margins. Apertural plane is flat without apparent thickening of the apertural margin. Sides of the shell steep, slightly convex, with increased curvature of the supra-apical surface towards the apex. Sub-apical surface strongly concave near apex, while adaperturally the surface is straight or weakly concave. The apex as it appears on internal moulds is simple and cap-shaped, without obvious demarcations. Surface of shell shows faint to obsolescent comarginal rugae or more distinct ribs (Fig. 14J-L). The shell is thin and conforms to the shape of the internal mould. Ornamentation consists of very fine comarginal lines.

Discussion: Kiær (1917) described Scenella antiqua n. sp., S. depressa n. sp. and Helcionella rugosa Hall (referred to as Helcionella cf. rugosa in the captions of Kiær, 1917) from the Holmia beds at Tømten. All specimens seem to come from the so-called Strenuella limestone, now the Evjevik Member of the Ringstrand Formation. Kiær (1917) mentions only one specimen of each species, except for Helcionella rugosa where he mentions two specimens but figures a very poorly preserved internal mould (Kiær, 1917, pl. 2, fig. 3 and interpretative drawings fig. 3a, b). Residing with the holotype in the collections at the Natural History Museum, Oslo, is a fairly well preserved external mould (PMO 24190) labelled Scenella antiqua (figured here in Fig. 14D-F). It is unclear how this specimen relates to the other specimens discussed by Kiær (1917), but it cannot be considered part of the type lot because there is nothing that directly allows an association with the originals listed by Kiær.

The addition of new material from the Mjøsa area as well as comparison with specimens from Gislöv and Mt Assjatj in Sweden (Kautsky, 1945; Ebbestad et al., 2009; Cederström et al., 2014) allows Kiær's taxa to be synonymised under the name Helcionella antiqua. The stratigraphical interval and associated fauna are also similar, 
and the variation seen in specimens is considered to be due to preservational conditions. Resser (1938) erected Helcionella kiaeri based on Scenella cf. rugosa sensu Kiær (1917), which here is considered a subjective junior synonym of Helcionella antiqua (Kiær, 1917). Helcionella? antiqua n. sp. Abaimova, 1976 was transferred to Purella by Qian \& Bengtson (1989).

Kautsky (1945) described Scenella sp. and Helcionella rugosa Hall var. lapponica from the Grammajukku Formation at Mt Assjatj, above the Holmia kjerulfi beds.
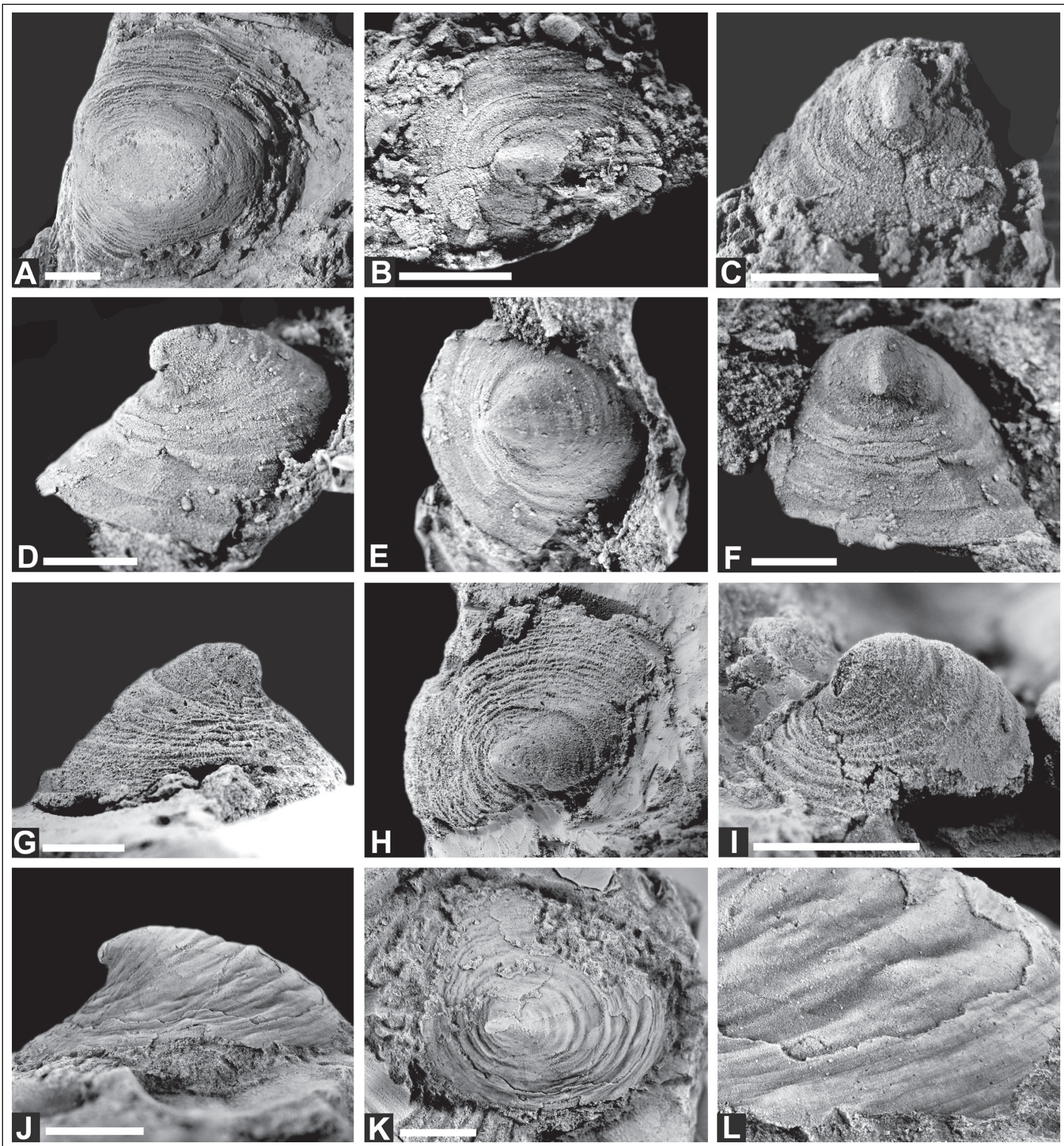

Figure 14. (A-L) Helcionella antiqua (Kicer, 1917): (A) Holotype, PMO 73172, internal mould, dorsal view, with posterior to the left. Evjevik Member, Tømten Farm. Figured by Kior (1917, pl. 2, fig. 1, 1a-c). (B, C) Dorsal and posterior views of latex cast of external mould, PMO 22892, originally described and figured as the type specimen of Scenella depressa by Kioer (1917, pl. 2, fig. 2, 2a-c). Evjevik Member, Tømten Farm. (D-F) Right, dorsal and posterior views of latex cast of external mould, PMO 24190. Evjevik Member, Tømten Farm. (G, H) Left and dorsal views of internal mould, PMO 227.682. Upper bed, Evjevik Member, Skyberg Farm. (I) Oblique right-posterior views of internal mould, PMO 227.683. Lower bed, Evjevik Member, Skyberg Farm. (J, K) Right and dorsal view of well-preserved internal mould with partly preserved shell, PMO 227.684. Ringstrand. (L) Close-up of J, showing ornamentation of fine, co-marginal lines. All scale bars: $3 \mathrm{~mm}$. 
Kautsky (1945, p. 203) remarked that they are very similar to the species described by Kiær (1917). One specimen is a small apical part, while the second is a larger, flattened specimen. There is nothing that distinguishes these from Helcionella antiqua as defined here, and they are therefore regarded as conspecific.

The Norwegian material and the type species, Helcionella subrugosa d'Orbigny from the lower Cambrian of Eastern Laurentia, appear very similar in both morphology and size, as judged from the photographs in Knight (1941), Lochman (1956) and Landing \& Bartowski (1996). The apex is not as far back in the Norwegian material and the comarginal rugae appear sharper in the American material, although individual variation of shell shape and expression of the ornament as a result of preservation, morphology and/or ontogeny are factors to consider. Ornamentation in the Norwegian material, as preserved, shows only fine concentric lines, although Kiær (1917, p. 18) reports radial ribs. Some specimens of the Swedish material examined show fine concentric lines crossed by sharper radiating lirae. Geyer (1986) suggested that Kiær's species belonged with the Moroccan genus Marocella Geyer, but other than a general resemblance in shell shape the concentric rugae and the sculpture serve to distinguish Helcionella antiqua from Marocella.

\section{Genus Stenotheca Salter in Hicks, 1872}

Type species: By original designation, Stenotheca cornucopia Salter in Hicks, 1872, p. 180, pl. 7, figs. 12-13, from the middle Cambrian Porth-y-rhaw Group (provisional series 3), of Porth-y-rhaw, St. David's, South Wales.

Remarks: Fairly large, tall, cyrtoconic, and laterally compressed shells of Stenotheca were initially described from the Cambrian of North America, Wales and France (Walcott, 1890; Cobbold, 1934, 1935; Landing, 1988, 1991; Bengtson et al., 1990) (e.g., S. acutacosta Walcott, 1890 from USA and Canada; S. cornucopia Salter in Hicks, 1872 from Wales; S. angusta Cobbold, 1935 and S. lata Cobbold, 1935 from France). Runnegar \& Jell (1976), Bengtson et al. (1990), Landing (1991), Landing \& Bartowski (1996) and Parkhaev (2004) introduced new species (list not exhaustive), while several North American variants and species were synonymised with S. acutacosta by Landing (1988).

Species attributed to Stenotheca have been removed from the genus (see for instance Landing, 1988; Parkhaev, 2004; Skovsted, 2004), and a consensus on the generic composition has clearly not been reached. A broadly similar genus is, for instance, Capitoconus Skovsted, 2004. It has a large, hemispherical and laterally compressed protoconch, a character that was used by Skovsted (2004) to distinguish it from Stenotheca, Parailsanella Zhegallo in Voronova et al., 1987, and Mellopegma Runnegar \& Jell, 1976. Capitoconus is known from the type species Capitoconus inclinatus Skovsted, 2004 and C. artus Skovsted, 2004 from the Bastion Formation in Northeast
Greenland. Skovsted (2004) tentatively included Helcionella sp. sensu Mackinnon (1985) from the middle Cambrian of New Zealand, as well as Latouchella sp. aff. iacobinica sensu Brock \& Cooper (1993) from the early Cambrian (Toyonian) of South Australia.

Stenotheca norvegica (Resser, 1938)

Fig. 15A-K

1917 Helcionella rugosa Hall var. acuticosta Walcott Kiær, p. 20, pl. 2, fig. 4.

1938 Helcionella norvegica n. sp., Resser, pp. 11, 14.

Type specimen: By original designation of Resser (1938, p. 14), PMO 24418 and counterpart PMO 24419. The originals of Kiær (1917), pl. 2, fig. 4, 4a, respectively. From the Evjevik Member at Tømten Farm, Ringsaker, Mjøsa area, Norway (refigured here in Fig. 15A).

Material: In addition to the specimen figured by Kiær (1917), thirteen new specimens (PMO 227.686-PMO 227.698), of which seven are figured. All are preserved as either internal or external moulds from the lower limestone bed of the Evjevik Member at Skyberg Farm.

Diagnosis: Shell large, elongated and narrow with a distinct lateral constriction near the posterior margin. Aperture strongly flared, creating at least fifteen increments with flared margins extending out from the shell. Transverse ornamentation of densely spaced lirae.

Description: Shell cyrtoconic, height between $1 / 2$ to $2 / 3$ of length, laterally compressed with the largest width being $1 / 3$ of length. The largest specimen is about 4.5 $\mathrm{mm}$ long. The supra-apical surface is gently convex, while the subapical margin is more strongly concave. Aperture elongated, drop shaped, being wider anteriorly. Both anterior and posterior margins are rounded. On the lateral sides towards the posterior the shell is constricted, almost as being pinched, creating a sunken flexure in the shell in lateral view (Fig. 15D, I-K). It starts almost at the subapical margin close to the apex and runs to the apertural margin. The curvature of the flexure is slightly less than that of the subapical margin, so that the centre of the flexure moves proportionally anteriorly during ontogeny. On internal moulds the constriction is clearly visible in lateral view, showing that it fans out and gets wider at the apertural margin. The apertural plane is essentially flat but curves adapically at the posterior margin creating a low sinus. Internal moulds have gentle symmetrical ribs with symmetrical shallow interareas in early ontogeny, while in later ontogeny the ribs form marked terraces that have a convex margin followed by a concave transition to the next rib. Ornamentation follows the ribs on the internal moulds and consists of a series of comarginal increments that are gently concave like the plaid of a skirt, and ending in a reflected margin extending some distance out from the shell (Fig. 14F). At least fifteen increments are present in large specimens, 
with the distance between increments increasing proportionally to the size increase of the shell. Perpendicular to the flared margins are densely spaced lirae (Fig. 14G) that get thicker during ontogeny, but only as a function of the proportional increase in size of the shell. The protoconch is cap-shaped and prominent.

Remarks: This is the most common helcionelloid in the Evjevik Member, but only found in the lower bed. There seems to be two distinct morphologies: a high form like the holotype (Fig. 15A-E, J), where the height is $2 / 3$ of the length, and a low form, where the height is corresponding to half the length (Fig. 15K). The general morphology and ornamentation is similar, so the forms are considered conspecific.

Kiær (1917) allied his single specimen from the Mjøsa area with Stenotheca acutacosta Walcott, 1890 from
Newfoundland, albeit treating it as a variant of Helcionella rugosa Hall due to the synonymy proposed by Grabau \& Shimer (1909) for this species. Resser (1938) pointed out the many problems with the treatment of Helcionella vs. Stenotheca by Grabau \& Shimer (1909) in relation to Walcott's species (Walcott, 1890). The Norwegian form was placed in a new species without further comments. Bengtson et al. (1990, fig. 163H-L) figured the type specimens of Stenotheca acutacosta, and it appears very similar to $S$. norvegica. The height of $S$. acutacosta is $6 \mathrm{~mm}$ compared to $4.5 \mathrm{~mm}$ in the largest specimen of $S$. norvegica, and the supra-apical curvature seems less prominent in the Canadian species. Furthermore, the number of growth increments may be fewer, the posterior elongation less prominent and the lateral constriction near the posterior margin seems to be missing. Possible morphological variants are unknown, so
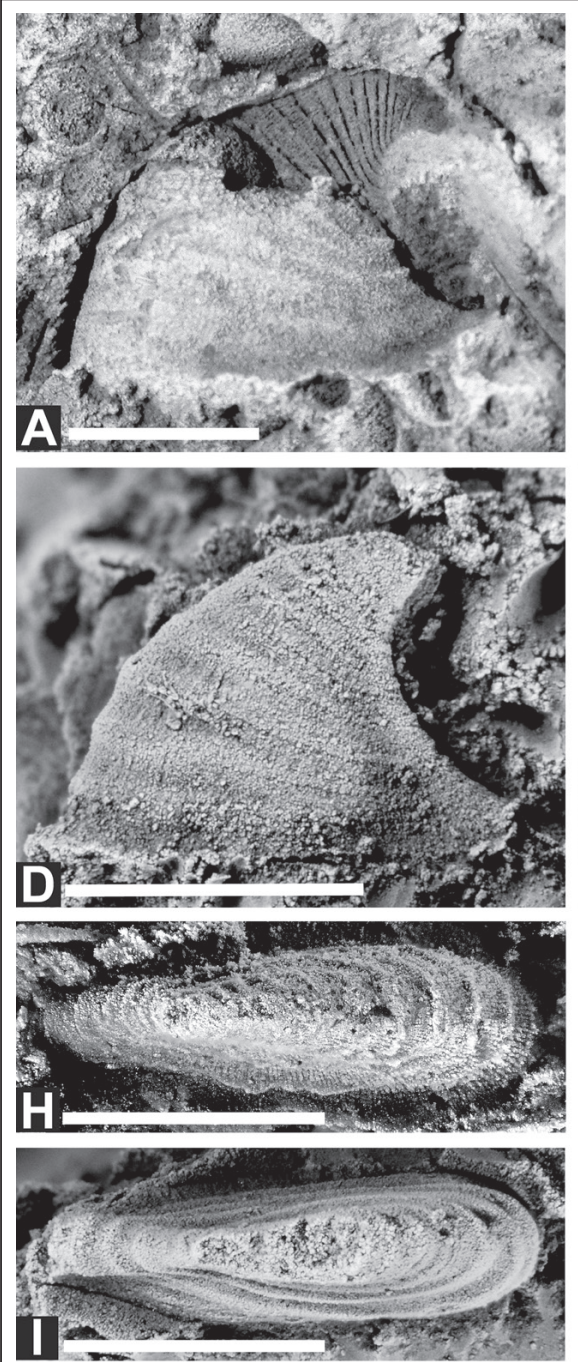
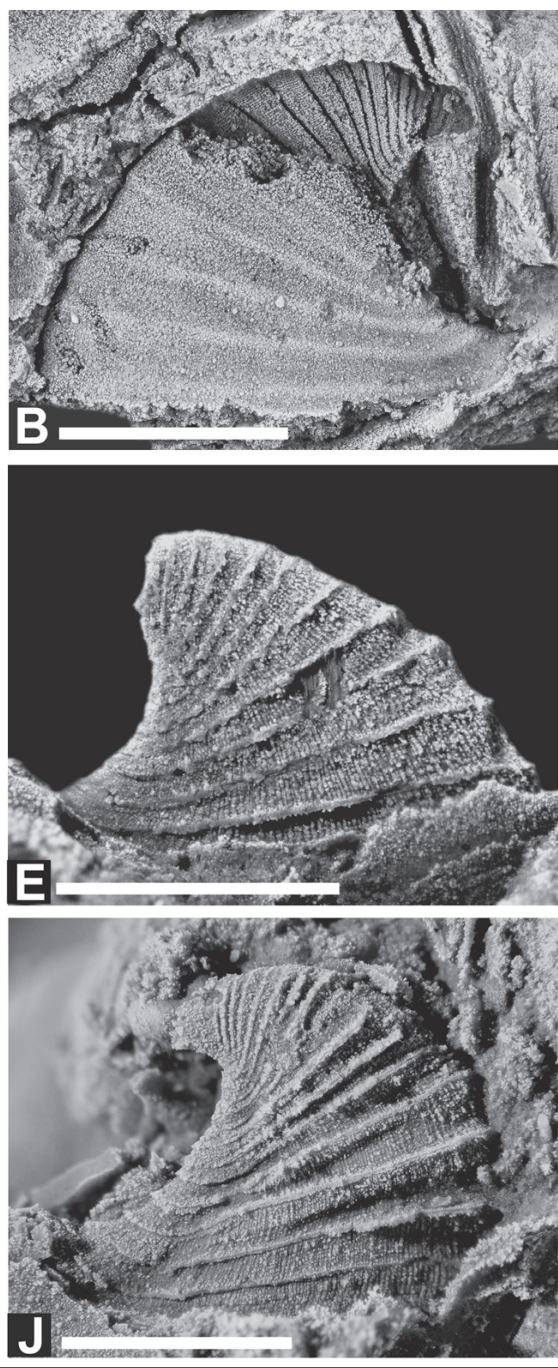

Figure 15. (A-K) Stenotheca norvegica (Resser, 1938). (A) Holotype, PMO 24418, internal and partly external mould, left view. Evjevik Member, Tømten Farm. Described and figured as Helcionella rugosa var. acuticosta by Kicer (1917, pl. 2, fig. 4). (B) Left view of internal and partly external mould, PMO 227.686. (C) Left view of silicon cast of external mould, PMO 227.687, showing distinct ornamentation. (D) Left view of internal mould, PMO 227.688. Note lateral constriction towards posterior margin. (E, $F, H)$ Right, anterior and dorsal views of silicon cast of PMO 227.689. Note flared margins or increments extending from the shell. (G, J) Right view of silicon cast, PMO 227.690. G is a close-up of J, showing densely spaced lirae perpendicular to the co-marginal increments. (I) Dorsal view of internal mould, PMO 227.691. Note lateral constriction towards posterior margin. (K) Left side of silicon cast, PMO 227.692, low morph with the height of the shell half the length. B-K from the lower bed, Evjevik Member, Skyberg Farm. All scale bars: $2 \mathrm{~mm}$. 
until S. acutacosta is better understood it is preferable to distinguish the two species.

Bengtson et al. (1990) treated S. acutacosta as a secondary standard for the type species $S$. cornucopia because the syntypes seem to be lost. The main difference between $S$. cornucopia and Stenotheca norvegica seems to be that the subapical margin is straight or slightly concave in the former. Once more, too little is known of the type species to make a full comparison.

Stenotheca norvegica is as well comparable to Capitoconus Skovsted, 2004, although the two species described from Greenland by Skovsted (2004) are minute compared to $S$. norvegica. The type species, C. inclinatus, seems to be proportionally broader, whereas $C$. artus compares closely in the overall shape (see for instance Skovsted, 2004, fig. 5L). S. norvegica seems to have fewer increments than C. artus, and the posterior constriction appears to be missing in the latter. Capitoconus artus also possesses the regularly flared comarginal ornamentation. In several helcionelloids the aperture forms a key-hole shape (sensu Peel, 1991b), like the prominent constriction seen in S. norvegica. Peel (1991b) described this feature in Eotebenna Runnegar \& Jell, 1976 and Lautochella Cobbold, 1921, proposing that it served to separate a posterior mantel cavity. Similar constrictions seem to be missing in Mellopegma, which otherwise have a similar narrow shell and posterior upturned curvature and development of a sinus at the apertural margin. In Mellopegma the apertural plane is not horizontal as it is in Stenotheca and Capitoconus.

\section{Genus Mackinnonia Runnegar in Bengtson et al., 1990}

Type species: By original designation of Runnegar in Bengtson et al. (1990): Mackinnonia davidi Runnegar in Bengtson et al.,1990, p. 233, from the lower Cambrian (Botomian) Parara Limestone at Horse Gully near Ardrossan, Yorke Peninsula, South Australia.

Remarks: The type species designated by Runnegar in Bengtson et al. (1990) was found by Parkahev (2001) to be a junior synonym of Mackinnonia rostrata (Zhou \& Xiao, 1984, p. 132, pl. 3, figs. 7-10), from the Atdabanian/Botomian Yutaishan Formation in the Huainan County, Anhui Province, China. Mackinnonia davidi still remains the type species, in accordance with the ICZN (1999) Article 67.1.2. "The name of a type species remains unchanged even when it is a junior synonym or homonym, or a suppressed name." Kouchinsky et al. (2015) questioned the synonymy suggested by Parkhaev (2001).

Parkhaev (2005) listed three species of Mackinnonia: M. rostrata (Zhou \& Xiao, 1984), M. plicata (Missarzhevsky, 1989) and M. anabarica Parkhaev, 2005. Leptostega? corrugata Runnegar in Bengtson et al. (1990) was synonymised with Mackinnonia plicata (Missarzhevsky, 1989) by Parkhaev (2001) but Skovsted (2004) kept M. corrugata as a distinct species. Skovsted (2004) also placed Stenotheca taconia Landing \& Bartowski, 1996 with Mackinnonia, although Parkhaev (2001) had made it the type species of his new genus Aequiconus.

Leptostega Geyer, 1986, resembles Mackinnonia, except that the type of the genus has alternating ribs on the narrow posterior margin. Geyer (1986) erected the genus including two species, Leptostega irregularis Geyer from Spain and Leptostega? sp. aff. cingulata (Cobbold, 1921) from Morocco. He included also Helcionella cingulata Cobbold in Leptostega, but $H$. cingulata was tentatively synonymised with Helcionella abrubta (Shaler \& Foerste, 1888) by Landing (1988). The specimen identified as Helcionella cingulata by Poulsen (1932) was tentatively referred to Capitoconus inclinatus Skovsted, by Skovsted (2004). An additional species is Leptostega hyperborea Parkhaev, 2005 from the Botomian and Amgan stages of the northern Siberian Platform, Russia (Parkhaev, 2005; Kouchinsky et al., 2011, 2015).

\section{Mackinnonia puppis n. sp.}

Fig. 16A-J

Etymology: From Latin puppis meaning the stern of a boat, alluding to the boat-shaped ribs on the internal moulds, with the more distinct posterior buttress.

Type specimen: PMO 227.699 (Fig. 16A-C), an external mould from the lower silty limestone bed of the Evjevik Member at Skyberg Farm.

Paratypes: Ten specimens (PMO 227.700-PMO 227.709), of which one is an external mould. All from the lower silty limestone bed of the Evjevik Member at Skyberg Farm.

Diagnosis: A large species of Mackinnonia, with a laterally compressed, triangular shell where the apex is shifted slightly posteriorly. Internal moulds with 6 or more thick, rounded, comarginal ribs that are accentuated anteriorly and posteriorly by an upturned knob so as to give the impression of a boat shape in lateral view.

Description: Shell laterally compressed, triangular with the apex shifted slightly posteriorly but not overhanging the posterior margin. Aperture elongated oval, with the rounded anterior and posterior margins slightly pointed, the latter more so than the anterior. The largest specimen is $6.5 \mathrm{~mm}$ long. The length is 2.5 times the width, while length and height are subequal. Apertural plane nearly flat, slightly upturned anteriorly and posteriorly. Internal moulds with thick, rounded, comarginal ribs that are accentuated anteriorly and posteriorly by an upturned knob (buttress or parietal train), creating a clear groove between the knob and the respective anterior or posterior margin (supra-apical or sub-apical grooves). The knobs on the posterior end are more prominent. The knobs do not outline a sinus or similar emarginations, as the aperture is entire. In lateral view the ribs and knobs give the impression of a boat shape, where the knobs are the upturned bow and stern. The ribs are symmetrical across 
the anterior and posterior surfaces. The lateral areas in between the ribs are gently concave. At least seven ribs are developed, but the earliest ribs are difficult to discern. Casts of external moulds reveal that the contours of the internal moulds are evened out, so that the ribs are more subdued laterally while the prominent knobs become obsolescent (Fig. 16A, H, J). Ornamentation may consist of fine comarginal lirae crossed by fine radial lirae. The protoconch is simple, cap shaped, but not clearly demarcated.

Discussion: The shape of the shell and especially that of the boat-like ribs on the internal moulds is very characteristic. It is difficult to compare with the type species owing to the size differences and lack of details on the internal moulds in the Norwegian species, but it appears that the outer surface was smooth, as shown by the silicon cast. In general, the external moulds from the Evjevik Member reveal good details, so the presence of any ornamentation on $M$. puppis would likely have been visible. The holotype of $M$. puppis is an external mould, demonstrating how the ribs on the internal moulds are effaced and the anterior and posterior knobs are obsolescent.

Internal moulds of $M$. corrugata are very similar to those of $M$. puppis, although the projection of the knobs in the former is less pronounced. In this character, $M$. puppis greatly resembles Leptostega irregularis Geyer, but besides being about twice the size, the number of ribs is greater, the posterior knobs are more distinct, the apex is in a more posterior position and the ribs do not alternate in the Norwegian material. In the minute Leptostega hyperborea Parkhaev, 2005 the apex is more central and the comarginal ribs are very well developed close to the apex and do not show alternation which may suggest a placement with Mackinnonia (see also Kouchinsky et al., 2011, 2015).
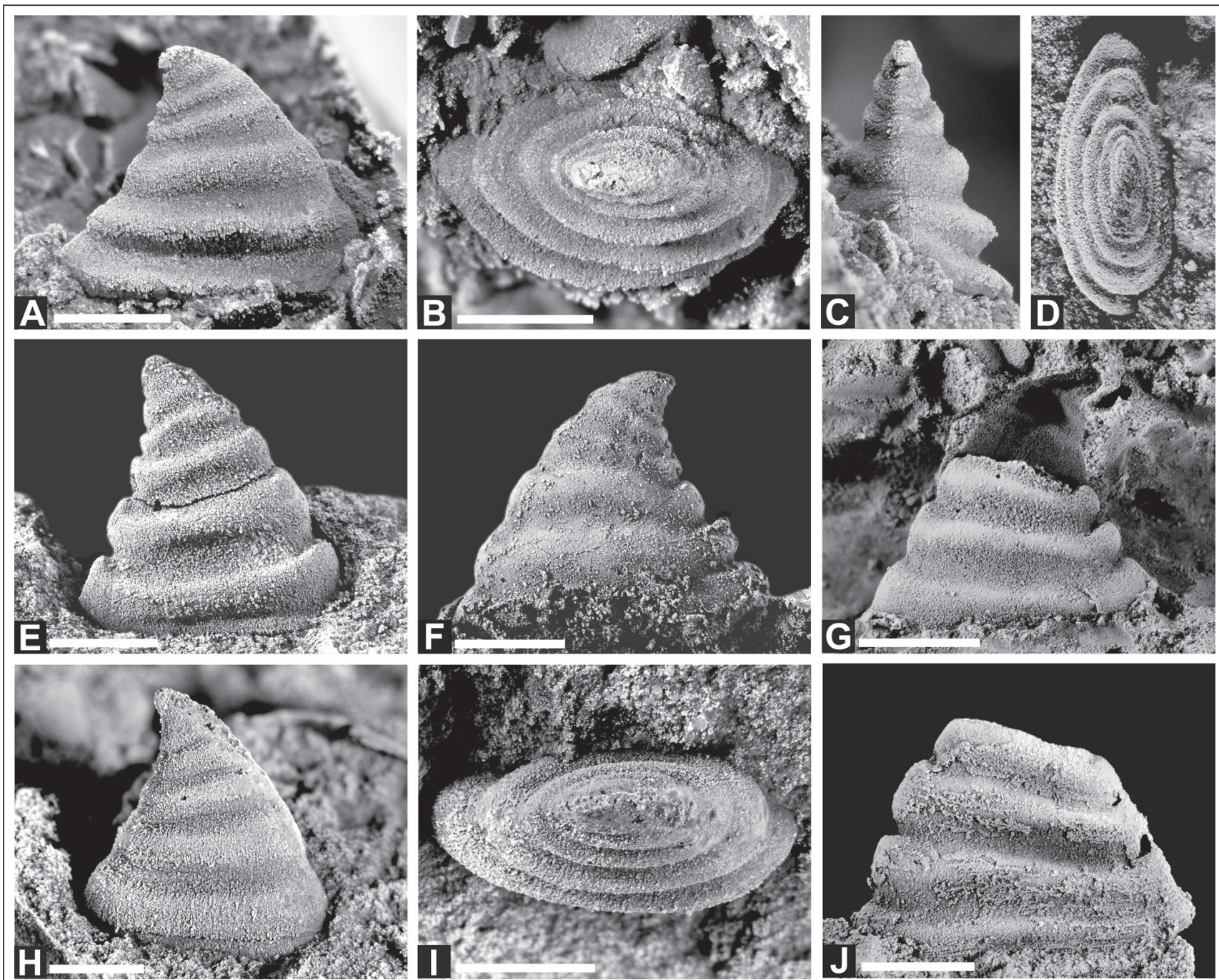

Figure 16. (A-J) Mackinnonia puppis n. sp. (A-C) Holotype, PMO 227.699. Right, dorsal and posterior views of silicon cast of external mould. $(D, E)$ Dorsal (posterior to the north) and right view of internal mould, PMO 227.700. (F) Left view of internal mould, PMO 227.701, showing co-marginal ribs ending in prominent, posterior knobs. (G) Left view of internal mould, PMO 227.702. (H, I) Right and dorsal views of silicon cast of external mould, PMO 227.703. (J) Left view of partly preserved internal mould, PMO 227.704, with partly preserved shell covering the prominent posterior knobs. All specimens from the lower bed, Evjevik Member, Skyberg Farm. All scale bars: $2 \mathrm{~mm}$. 

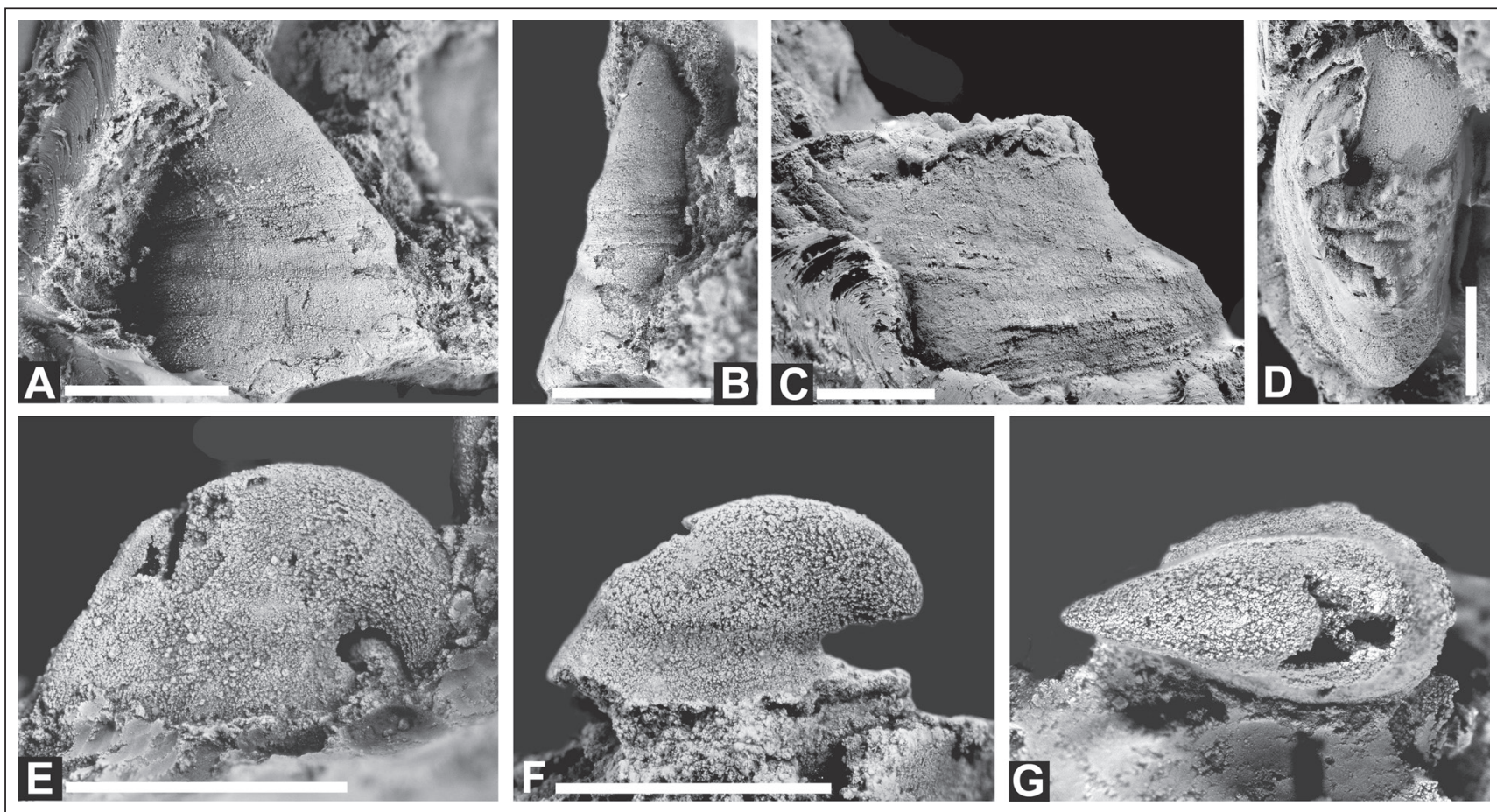

Figure 17. (A-D) Mackinnonia? sp. (A, B) Right and anterior views of latex cast of external mould, PMO 227.710. Note faint growth increments at the middle of the shell. $(C, D)$ Left and dorsal (posterior to the south) views of latex cast of an external mould, PMO 227.711. Note posterior expansion of the basal part. Both specimens from the upper bed, Evjevik Member, Skyberg Farm. (E-G) Latouchella sp. (E) Left view of internal mould, PMO 227.712. (F, G) Left and dorsal views of an internal mould, PMO 227.713. Note constriction at the aperture. Posterior to the left in G. Both specimens from the lower bed, Evjevik Member, Skyberg Farm. All scale bars: $2 \mathrm{~mm}$.

\section{Mackinnonia? sp.}

Fig. 17A-D

Material: Two external moulds (PMO 227.710, PMO 227.711) from the upper silty limestone bed of the Evjevik Member at Skyberg Farm.

Description: This is a conical form, compressed laterally, with the apex placed slightly posteriorly, but not overhanging the posterior margin. Height and width appear subequal, with the length of the shell being around $5 \mathrm{~mm}$. The sides are steep, straight or slightly concave, with faint indications of comarginal ribs. The apertural plane is flat, egg-shaped and with the narrow part being posterior. The subapical surface is gently concave while the foot of the shell seems to expand posteriorly (Fig. 17C). The ornamentation consists of fine comarginal and radial lirae. In places the comarginal sculpture shows growth increments.

Discussion: These two specimens can be distinguished from Mackinnonia puppis n.sp. in the lower bed of the Evjevik Member by the faintly indicated comarginal ribs, by the straight or concave lateral surfaces and the more egg-shaped form of the aperture. There is also seemingly a posterior expansion of the basal part of the shell.
Genus Latouchella Cobbold, 1921

Type species: By original designation, Latouchella costata Cobbold, 1921, p. 366, pl. 24, figs. 41, 42, from the Comley Limestone (Cambrian provisional series 2, stage 4) of Shropshire, England.

\section{Latouchella sp.}

Fig. 17E-G

Material: Three internal moulds (PMO 227.712-PMO 227.714) from the lower silty limestone bed of the Evjevik Member at Skyberg Farm, of which two are figured herein.

Discussion: These poorly preserved specimens are referred to Latouchella on the basis of the overall size and shape of the shell, which is comparable to the internal moulds of the type suite of Latouchella costata Cobbold, 1921 from England. The largest Norwegian specimen is just over $3 \mathrm{~mm}$ long, as is the holotype of L. costata. The main difference is that plications are not preserved in the Norwegian material. Two specimens (PMO 227.713, Fig. 17F, G and PMO 227.714, not figured) show constrictions at the aperture, but otherwise the moulds are smooth. 


\section{Conclusions}

The trilobite species Strenuella linnarssoni Kiær, 1917 is transferred to Ellipsocephalus. The Ellipsocephalus linnarssoni Zone is defined as an interval zone spanning the entire lower Cambrian Evjevik Member of the Ringstrand Formation in the Lower Allochthon in the Mjøsa area, Norway, and is overlain by the Comluella?-Ellipsocephalus lunatus Zone in the Skyberg Member. It is suggested that the Evjevik Member is coeval with the $40 \mathrm{~cm}$ thick siltstone unit in the lower part of the Gislöv Formation, Scania, Sweden; together with the lower E. linnarssoni Zone of the upper part of the same formation. The Skyberg Member is suggested to be coeval with the upper E. linnarssoni Zone in the upper part of the Gislöv Formation, comprising the Comluella?-Ellipsocephalus lunatus Zone. The number of described trilobite taxa from the Evjevik Member is increased, of which Holmia cf. lapponica, Ornamentaspis? sularpensis and Calodiscus lobatus are described and illustrated from Norway for the first time, together with two unassigned trilobite taxa. Three of the helcionelloid taxa described by Kiær (1917) from the Strenuella linnarssoni Zone (Evjevik Member) at Tømten Farm are considered conspecific, representing Helcionella antiqua. Helcionella norvegica Resser, 1938, originally described as Helcionella rugosa var. acuticosta by Kiær (1917), is transferred to Stenotheca. The number of helcionelloid taxa from the Evjevik Member is increased, of which Mackinnonia puppis n. sp., Mackinnonia sp. and Latouchella sp. are described and figured from Norway for the first time, together with the widespread enigmatic fossil Mongolitubulus Missarzhevsky, 1977. Helcionelloids may prove to be important tools for intercontinental correlation.

Acknowledgements. Peter Cederström, Eslöv, Sweden, is thanked for the loan of important comparative material from Swedish localities, and May-Liss Knudsen Funke, Natural History Museum, Oslo, is thanked for participating in the fieldwork. The reviewers Arne Thorshøj Nielsen, Natural History Museum, Denmark, and Ed Landing, New York State Museum, USA, are thanked for useful comments which improved the text.

\section{References}

Abaimova, G.P. 1976: Samyie drievnije gastropody Sibiri [The oldest gastropods of Sibiria]. Trudy Instituta Geologii i Geofiziki SO AN SSSR 296, 174-176. (In Russian).

Ahlberg, P. 1979: Early Cambrian trilobites from mount Luopakte northern Sweden. Sveriges Geologiska Undersökning C 765, 1-12.

Ahlberg, P. 1980: Early Cambrian trilobites from northern Scandinavia. Norsk Geologisk Tidsskrift 60, 153-159.

Ahlberg, P. 1983a: A Lower Cambrian trilobite fauna from Jämtland, central Scandinavian Caledonides. Geologiska Föreningens i Stockholm Förhandlingar 105, 349-361.

Ahlberg, P. 1983b: Redescription of a Lower Cambrian eodiscid trilobite from Norway. Norsk Geologisk Tidsskrift 63, 289-290.
Ahlberg, P. 1984: Lower Cambrian trilobites from the Laisvall area, northern Sweden. Geologiska Föreningens i Stockholm Förhandlingar 105, 251-259.

Ahlberg, P. \& Bergström, J. 1978: Lower Cambrian ptychopariid trilobites from Scandinavia. Sveriges Geologiska Undersökning C 49, $1-41$.

Ahlberg, P. \& Bergström, J. 1983: Lower Cambrian trilobites from southern Swedish Lapland. Geologiska Föreningens i Stockholm Förhandlingar 104, 241-246.

Ahlberg, P. \& Bergström, J. 1993: The trilobite Calodiscus lobatus from the Lower Cambrian of Scania, Sweden. Geologiska Föreningens $i$ Stockholm Förhandlingar 115, 331-334.

Ahlberg, P., Bergström, J. \& Johansson, J. 1986: Lower Cambrian olenellid trilobites from the Baltic Faunal Province. Geologiska Föreningens i Stockholm Förhandlingar 108, 39-56.

Álvaro, J.J., Ahlberg, P. \& Axheimer, N. 2010: Skeletal carbonate productivity and phosphogenesis at the lower-middle Cambrian transition of Scania, southern Sweden. Geological Magazine 147, 59-76.

Álvaro, J.J., Zamora, S., Vizcaïno, D. \& Ahlberg, P. 2012: Guzhangian (mid Cambrian) trilobites from siliceous concretions of the Valtorres Formation, Iberian Chains, NE Spain. Geological Magazine 150, 123-142.

Angelin, N.P. 1851: Palæontologia Suecica. Pars I. Iconographica Crustaceorum Formationis Transitionis Fasc. I. Weigel, Lund. 24 pp.

Axheimer, N., Ahlberg, P. \& Cederström, P. 2007: A new lower Cambrian eodiscoid trilobite fauna fom Swedish Lapland and its implications for intercontinental correlation. Geological Magazine 144, 953-961.

Bengtson, S. 1980: Redescription of the Lower Cambrian Lapworthella cornu. Geologiska Föreningen i Stockholm Förhandlingar 102, 53-55.

Bengtson, S., Conway Morris, S., Cooper, B.J., Jell, P.A. \& Runnegar, B.N. 1990: Early Cambrian fossils from South Australia. Association of Australasian Palaeontologists Memoir 9, 364 pp.

Berg-Madsen, V. 1985: The Middle Cambrian of Bornholm, Denmark: A stratigraphical revision of the Lower Alum Shale and associated anthraconites. Geologiska Föreningens $i$ Stockholm Förhandlingar 106, 357-376.

Berg-Madsen, V. \& Peel, J.S. 1978: Middle Cambrian monoplacophorans from Bornholm and Australia, and the systematic position of the bellerophontiform molluscs. Lethaia 11, 113-125.

Berg-Madsen, V. \& Peel, J.S. 1986: Scenella barrandei (Mollusca) from the Middle Cambrian of Baltoscandia. Norsk Geologisk Tidsskrift $66,81-86$.

Berg-Madsen, V. \& Peel, J.S. 1987: Yochelcionella (Mollusca) from the late Middle Cambrian of Bornholm, Denmark. Bulletin of the Geological Society of Denmark 36, 259-261.

Bergström, J. 1973: Classification of olenellid trilobites and some Balto-Scandian species. Norsk Geologisk Tidsskrift 53, 283-314.

Bergström, J. \& Ahlberg, P. 1981: Uppermost Lower Cambrian biostratigraphy in Scania, Sweden. Geologiska Föreningens i Stockholm Förhandlingar 103, 193-214.

Brock, G.A \& Cooper, B.J. 1993: Shelly fossils from the Early Cambrian (Toyonian) Wirrealpa, Aroona Creek, and Ramsay limestone of South Australia. Journal of Paleontology 67, 758-778.

Brøgger, W.C. 1878: Om Paradoxidesskifrene ved Krekling. Nyt Magazin for Naturvidenskaberne 24, 18-88. 
Buchholz, A. 2010: Geschiebe des mittelkambrischen Fragmentkalkes von Bornholm (Andrarumkalk-Brekzie) aus Vorpommern (Nordostdeutschland): Lithologie und Fauna. Geschiebekunde aktuell 26, 75-100.

Caron, J.-B., Smith, M.R. \& Harvey T.H.P. 2013: Beyond the Burgess Shale: Cambrian microfossils track the rise and fall of hallucigeniid lobopodians. Proceedings of the Royal Society B 280: 20131613, http://dx.doi.org/10.1098/rspb.2013.1613.

Cederström, P., Ahlberg, P., Clarkson, E.N.K., Nilsson, C.H. \& Axheimer, N. 2009: The Lower Cambrian eodiscoid trilobite Calodiscus lobatus from Sweden: Morphology, ontogeny and distribution. Palaeontology 52, 491-539.

Cederström, P., Ahlberg, P., Nilsson, C.H., Ahlgren, J. \& Erikson M.E. 2010: Moulting, ontogeny and sexual dimorphism in the Cambrian ptychopariid trilobite Strenuaeva inflata from the Northern Swedish Caledonides. Palaeontology 53, 1-19.

Cederström, P., Ahlberg, P., Babcock, L.E., Ahlgren, J., Høyberget, M. \& Nilsson, C.H. 2012: Morphology, ontogeny and distribution on the Cambrian Series 2 ellipsocephalid trilobite Strenuaeva spinosa from Scandinavia. Geologiska Föreningens i Stockholm Förhandlingar 134, 157-171.

Cederström, P., Ebbestad, J.O.R. \& Ahlberg, P. 2014: Helcionelloid molluscs from Cambrian Series 2 strata in Sweden: Composition and stratigraphic implications. Abstracts, 31st Nordic Geological Winter Meeting, 8-10 January, Lund, Sweden, p. 66.

Cobbold, E.S. 1921: The Cambrian horizons of Comley (Shropshire) and their Brachiopoda, Pteropoda, Gastropoda, etc. Quarterly Journal of the Geological Society of London 76, 325-386.

Cobbold, E.S. 1934: The Genus Stenotheca. Geological Magazine 71, 463-468.

Cobbold, E.S. 1935: Lower Cambrian faunas from Hérault, France. Annals and Magazine of Natural History. Series 10, 16, 325-386.

d'Orbigny, A. 1850: Prodrome de Paléontologie Stratigraphique Universelle des Animaux Mollusques et Rayonnés faisant suite au cours élémentaire de Paléontologie. Tome 1. Masson, Paris, 427 pp.

Dzik, J. 2003: Early Cambrian lobopodian sclerites and associated fossils from Kazakhstan. Palaeontology 46, 93-112.

Ebbestad, J.O.R., Peel, J.S., Cederström, P. \& Ahlgren, J. 2009: Helcionelloid molluscs from the Lower Cambrian of Southern Sweden. Abstracts with programme, Lundadagarna i Historisk Geologi och paleontologi XI, 11-12 March, Lund, Sweden.

Ebbestad, J.O.R., Högström, A.E.S., Høyberget, M., Jensen, S., Palacios, T. \& Taylor, W.L.T. 2014: Trilobites of the Lower Cambrian Duolbasgaissa Formation, The Digermul Peninsula, northern Norway. Abstracts, 31st Nordic Geological Winter Meeting, 8-10 January, Lund, Sweden, p. 66.

Fletcher, T.P., Theokritoff, G., Lord, G.S. \& Zeoli, G. 2005: The early paradoxidid Harlani trilobite fauna of Massachussets and its correlatives in Newfoundland, Morocco and Spain. Journal of Paleontology 79, 312-336.

Frech, F. 1897: Lethaea geognostica oder Beschreibung und Abbildung der für die Gebirgs-Formationen bezeichnendsten Versteinerungen. I. Theil. Lethaea palaeozoica. 2. Band. IV. Schweizerbart, Stuttgart, $256 \mathrm{pp}$.

Geyer, G. 1986: Mittelkambrische Mollusken aus Marokko und Spanien. Senckenbergiana lethaea 67, 55-118.

Geyer, G. 1990: Die marokkanischen Ellipsocephalidae (Trilobita: Redlichiida). Beringeria 3, 1-363.
Geyer, G. 1994: Middle Cambrian mollusks from Idaho and early conchiferan evolution. New York State Museum Bulletin 481, 69-86.

Geyer, G. \& Landing, E. 2001: Middle Cambrian of Avalonian Massachusetts: stratigraphy and correlation of the Braintree trilobites. Journal of Paleontology 75, 116-135.

Geyer, G., Popp, A., Weidner, T. \& Förster, L. 2004: New Lower Cambrian trilobites from Pleistocene erratic boulders of northern Germany and Denmark and their bearing on the intercontinental correlation. Paläontologische Zeitschrift 78, 127-136.

Grabau, A.W. \& Shimer, H.W. 1909: North American Index FossilsInvertebrates, Volume 1. A.G. Seoler \& Co., New York, 893 pp.

Grönwall, K.A. 1902: Bornholms Paradoxideslag og deres fauna. Danmarks geologiske Undersøgelse, II Reekke, 13, 1-230.

Gubanov, A.P. \& Peel, J.S. 1999: Oelandiella, the earliest Cambrian helcionelloid mollusc from Siberia. Palaeontology 42, 211-222.

Gubanov, A.P. \& Peel, J.S. 2000: Cambrian monoplacophoran molluscs (Class Helcionelloida). American Malacological Bulletin 15, 139145.

Hall, J. 1847: Natural History of New York. Palaeontology: Volume 1. Containing decriptions of the organic remains of the lower division of the New-York System. C. Van Benthuysen, Albany, New York, 338 pp.

Henningsmoen, G. 1959: Family Ellipsocephalidae. In Moore R.C. (ed.): Treatise on Invertebrate Paleontolgy, part O, Arthropoda 1. Geological Society of America and University of Kansas Press, Lawrence, pp. O207-O209.

Hicks, H. 1872: On some undescribed fossils from the Mendevian Group. Quarterly Journal of the Geological Society of London 28, 173-185.

Hinz, I. 1987: The Lower Cambrian microfauna of Comley and Rushton, Shropshire/England. Palaeontographica A 198, 41-100.

Holm, G. 1887: Om Olenellus Kjerulfi Linrs. Geologiska Föreningens $i$ Stockholm Förhandlingar 9, 493-522.

Howell, B.F. 1935: Cambrian and Ordovician trilobites from Hérault, southern France. Journal of Paleontology 9, 222-238.

Hupé, P. 1953: Contribution à létude du Cambrien inférieur et du Précambrian III de l'Anti- Atlas Marocain. Direction de la Production Industrielle et des Mines, Division des Mines et de la Géologie, Service Géologique, Notes et Mémoires 103, 1-402.

Høyberget, M. \& Bruton, D.L. 2008: Middle Cambrian trilobites of the suborders Agnostina and Eodiscina from the Oslo Region, Norway. Palaeontographica A 286, 1-87.

International Commission on Zoological Nomenclature 1999: The International Code of Zoological Nomenclature. International Trust for Zoological Nomenclature, Natural History Museum, London, $124 \mathrm{pp}$.

Jell, P.A. 1990: Trilobita. In Bengtson, S., Conway Morris, S., Cooper, B.J., Jell, P.A. \& Runnegar, B.N. (eds.): Early Cambrian fossils from South Australia, Memoir of the Association of Australian Palaeontolgists 9, pp. 175-203, figs. pp. 257-322.

Kautsky, F. 1945: Die Unterkambrische Fauna vom Aistjakk in Lapland. Geologiska Föreningens i Stockholm Förhandlingar 67, 129-211.

Kautsky, F. 1962: Phylogenetische Studien an fossilen Invertebraten. Sveriges Geologiska Undersökning C 581, 1-164.

Kiær, J. 1917: The Lower Cambrian Holmia fauna at Tømten in Norway. Norske Videnskapsselskapets Skrifter, I. Matematisk-Naturvitenskablig Klasse 1916 10, 1-140.

Knight, J.B. 1941: Paleozoic gastropod genotypes. Geological Society of America, Special Paper 32, 1-510. 
Kobayashi, T. 1939: Restudy on Lorenz's Raphistoma bröggeri from Shantung with a note on Pelagiella. Jubilee publication in commemoration of Professor H. Yabe's 60th birthday, 283-288.

Kobayashi, T. 1943: Brief notes on the eodiscids 1, their classification with a description of a new species and a new variety. Proceedings of the Imperial Academy, Tokyo 19, 37-42.

Kouchinsky, A., Bengtson, S., Clausen, S., Gubanov, A.P., Malinky, J.M. \& Peel, J.S. 2011: A Middle Cambrian fauna of skeletal fossils from the Kuonamka Formation, northern Siberia. Alcheringa 35, 123-189.

Kouchinsky, A., Bengtson, S., Clausen, S. \& Vendrasco, M.J. 2015: A lower Cambrian fauna of skeletal fossils from the Emyaksin Formation, northern Siberia. Acta Palaeontologica Polonica 60, 421-512, http://dx.doi.org/10.4202/app.2012.0004.

Landing, E. 1988: Lower Cambrian of Eastern Massachusetts: Stratigraphy and Small Shelly Fossils. Journal of Paleontology 62, 661-695.

Landing, E. 1991: Upper Precambrian through Lower Cambrian of Cape Breton Island: faunas, paleoenvironments, and stratigraphic revision. Journal of Paleontology 65, 570-595.

Landing, E. \& Bartowski, K.E. 1996: Oldest Shelly Fossils from the Taconic Allochthon and Late Early Cambrian Sea-Levels in Eastern Laurentia. Journal of Paleontology 70, 741-761.

Lendzion, K. 1972: Stratigrafiya kambrn dolnego na obszarze podlasia [The stratigraphy of the Lower Cambrian in the Podlasie area]. Biuletyn Instytut Geologiczny 233, 69-157. (In Russian).

Lermontova, E.V. 1940: Klass Gastropoda (Class Gastropoda). In Vologdin A.G. (ed.): Atlas rukovodyashchikhform iskopaemykhfaun SSSR, T. 1: Kembriy [Atlas of the 1ndex Forms of Fossil Faunas of the USSR, V. I: Cambrian], Gosgeolizdat, Leningrad, Moscow, pp. 108111. (In Russian).

Li, G., Steiner, M., Zhu, M. \& Zhao, X. 2012: Early Cambrian eodiscoid trilobite Hupeidiscus orientalis from South China: ontogeny and implications for affinities of Mongolitubulus-like sclerites. Bulletin of Geosciences 87, 159-169.

Lieberman, B.S. 1998: Cladistic Analysis of the Early Cambrian Olenelloid Trilobites. Journal of Paleontology 72, 59-78.

Lieberman, B.S. 1999: Systematic Revision of the Olenelloidea. Bulletin of the Peabody Museum of Natural History 45, 1-150.

Lieberman, B.S. 2002: Phylogenetic Analysis of Some Basal Early Cambrian Trilobites, the Biogeographic Origins of the Eutrilobita, and the Timing of the Cambrian Radiation. Journal of Paleontology 76, 692-708.

Linnarsson, G. 1871: Om några försteningar från Sveriges och Norges "primordialzon". Öfversikt af Kungliga Vetenskaps-Akademiens Förhandlingar 6, 789-796.

Linnarsson, G. 1879: Om faunan i kalken med Conocoryphe exsulans (“Coronatuskalken”). Sveriges Geologiska Undersökning C 35, 1-31.

Linnarsson, G. 1883: De undre Paradoxideslagren vid Andrarum. Sveriges Geologiska Undersökning C 54, 1-48.

Lochman, C. 1956: Stratigraphy, paleontology, and paleogeography of the Elliptocephala asaphoides strata in Cambridge and Hoosick Quadrangles, New York. Bulletin of the Geological Society of America 67, 1331-1396.

MacKinnon, D.I. 1985: New Zealand late Middle Cambrian molluscs and the origin of Rostroconchia and Bivalvia. Alcheringa 9, 65-81.

Marcou, J. 1890: The Lower and Middle Taconic of Europe and North America. The American Geologist 5, 357-375.

Matthew, G.F. 1887: Illustrations of the fauna of the St. John Group, No. 4. On the small-eyed trilobites of Division I, with a few remarks on the species of higher divisions of the group. Canadian Record of Science 2, 357-363.
Matthew, G.F. 1889: Cambrian rocks in Acadia. The Canadian Record of Science 3, 71-81.

Matthew, G.F. 1890: On Cambrian organisms in Acadia. Royal Society of Canada, Proceedings and Transactions 7, 135-162.

Missarzhevsky, V.V. 1977: Konodonty (?) i fosfatnaya problematika kembriya Mongolii i Sibiri [Conodonts (?) and phosphatic Problematica of the Cambrian from Mongolia and Siberia]. Trudy, Sovmestnaya Sovetsko-Mongol'skaya paleontologicheskaya ekspeditsiya, 10-19. Nauka, Moscow. (In Russian).

Missarzhevsky, V.V. 1989: Drevnejshie skeletnye okamenelosti i stratigrafiya pogranichnykh tolshch dokembriya i kembriya. [The oldest skeletal fossils and stratigraphy of the Precambrian-Cambrian boundary beds]. Trudy Geologičeskogo Instituta AN SSSR 443, 237 pp. (In Russian).

Moczydłowska, M. 2002: Early Cambrian phytoplankton diversification and appearance of trilobites in the Swedish Caledonides with implications for coupled evolutionary events between primary producers and consumers. Lethaia 35, 191-214.

Moczydłowska, M., Jensen, S., Ebbestad, J.O.R., Budd, G.E. \& MartíMus, M. 2001: Biochronology of the autochthonous Lower Cambrian in the Laisvall-Storuman area, Swedish Caledonides. Geological Magazine 138, 435-453.

Münster, T. 1900: Kartbladet Lillehammer. Norges Geologiske Undersøgelse 30, 1-49.

Nielsen, A.T. \& Schovsbo, N.H. 2007: Cambrian to basal Ordovician lithostratigraphy in southern Scandinavia. Bulletin of the Geological Society of Denmark 53, 47-92.

Nielsen, A.T. \& Schovsbo, N.H. 2011: The Lower Cambrian of Scandinavia: Depositional environment, sequence stratigraphy and palaeogeography. Earth Science Reviews 107, 207-310.

Nikolaisen, F. 1986: Olenellid trilobites from the uppermost Lower Cambrian Evjevik Limestone at Tømten in Ringsaker, Norway. Norsk Geologisk Tidsskrift 66, 305-309.

Nikolaisen, F. \& Henningsmoen, G. 1987: Lower and Middle Cambrian trilobites from the Digermul Peninsula, Finnmark, northern Norway. Norges Geologiske Undersøkelse, Bulletin 419, 55-95.

Öpik, A.A. 1975: Cymbric Vale Fauna of New South Wales and Early Cambrian Biostratigraphy. Bureau of Mineral Resources, Geology and Geophysics, Bulletin 159, 1-78.

Palmer, A.R. \& Repina L.N. 1993: Through a glass darkly: Taxonomy, phylogeny, and biostratigraphy of the Olenellina. The University of Kansas Paleontological Contributions 3, 1-35.

Palmer, A.R. \& Repina L.N. 1997: Introduction to the Suborder Olenellina. In Kaesler, R.L. (ed.): Treatise on ivertebrate paleontolgy. Part O. Arthropoda 1. Trilobita, Revised. Volume 1, Geological Society of America and University of Kansas, Boulder, Colorado and Lawrence, Kansas, pp. 405-429.

Parkhaev, P.Yu. 2001: Molluscs and siphonoconchs. In Alexander E.M., Jago, J.B, Rozanov, A.Yu. \& Zhuravlev, A.Yu. (eds.): The Cambrian biostratigraphy of the Stansbury Basin, South Australia, Transactions of the Palaeontological Institute 282, pp. 133-210.

Parkhaev, P.Yu. 2002: Phylogenesis and the System of the Cambrian Univalved Molluscs. Paleontological Journal 36, 27-39.

Parkhaev, P.Yu. 2004: Malacofauna of the Lower Cambrian Bystraya Formation of Eastern Transbaikalia, Paleontological Journal 38, 590-608.

Parkhaev, P.Yu. 2005: Two new species of the Cambrian helcionelloid molluscs from the northern part of the Siberian Platform. Paleontological Journal 39, 615-619. 
Peel, J.S. 1991a: Functional morphology of the Class Helcionelloida nov., and the early evolution of the Mollusca. In Simonetta, A. \& Conway Morris, S. (eds.): The early evolution of Metazoa and the significance of problematic taxa. Cambridge University Press, Cambridge, pp. 157-177.

Peel, J.S. 1991b: The Class Tergomya and Helcionelloida, and early molluscan evolution. Bulletin Grønlands Geologiske Undersøgelse 161, 11-65.

Peel, J.S. \& Yochelson, E.L. 1987: New information on Oelandia (Mollusca) from the Middle Cambrian of Sweden. Bulletin of the Geological Society of Denmark 36, 263-273.

Poulsen, C. 1932: The Lower Cambrian faunas of East Greenland. Meddelelser om Grønland 87, 1-66.

Poulsen, C. 1969: The Lower Cambrian from Slagelse no.1, Western Sealand. Danmarks Geologiske Undersøgelse, II Raekke, 93, 5-27.

Qian Yi \& Bengtson, S. 1989: Palaeontology and biostratigraphy of the Early Cambrian Meishucunian Stage in Yunnan Province, South China. Fossils and Strata 24, 1-156.

Raymond, P.E. 1913: On the genera of the Eodiscidae. The Ottawa Naturalist 27, 101-106.

Resser, C.E. 1938: Fourth contribution to nomenclature of Cambrian fossils. Smithsonian Miscellaneous Collections 97, 1-43.

Richter, R. \& Richter, E. 1940: Studien im Paläozoikum der MittelmeerLänder, 5: Die Saukianda-Stufe von Andalusien, eine fremde Fauna im europäischen Ober-Kambrium. Abhandlungen der Senckenbergischen Naturforschenden Gesellschaft 450, 1-81

Runnegar, B. \& Jell, P.A. 1976: Australian Middle Cambrian molluscs and their bearing on early molluscan evolution. Alcheringa l, 109-138.

Rushton, A.W.A. 1966: The Cambrian trilobites from the Purley Shales of Warwickshire. Monographs of the Palaeontographical Society 120, 1-55.

Schlotheim, E.F. von 1823: Nachträge zur Petrefactenkunde. Zweyte Abtheilung. Beckersche Buchhandlung, Gotha, 114 pp.

Sdzuy, K. 1961: Das Kambrium Spaniens. Teil II: Trilobiten. Akademie der Wissenschaften und der Literatur, Abhandlung der Mathematische-Naturwissenschaftligen Klasse, 1961, 499-594.

Shaler, N.S \& Foerste, A.F. 1888: Preliminary description of North Attleboro fossils. Harvard Museum of Comparative Zoology Bulletin 16, 27-41.

Shergold, J.H. \& Brasier, M.D. 1986: Biochronology of Proterozoic and Cambrian phosphorites. In Cook, P.J. \& Shergold, J.H. (eds.): Phosphate Deposits of the World, Volume 1. Proterozoic and Cambrian Phosphorites. Cambridge University Press, Cambridge, pp. 295-326.

Skjeseth, S. 1963: Contributions to the geology of the Mjøsa Districts and the classical sparagmite area in southern Norway. Norges Geologiske Undersøkelse 220, 1-126.

Skovsted, C.B. 2004: Mollusc fauna of the Early Cambrian Bastion Formation of North-East Greenland. Bulletin of the Geological Society of Denmark 51,11-37.

Skovsted, C.B. 2005: A carapace of the bradoriid arthropod Mongolitubulus from the Early Cambrian of Greenland. Geologiska Föreningens i Stockholm Förhandlingar 127, 217-220.

Skovsted, C.B. \& Peel, J.S. 2001: The problematic fossil Mongolitubulus from the Lower Cambrian of Greenland. Bulletin of the Geological Society of Denmark 48, 135-147.

Skovsted, C.B., Brock, G.A. \& Paterson, J.R. 2006: Bivalved arthropods from the Lower Cambrian Mernmerna Formation of South Australia and their implications for the identification of Cambrian 'small shelly fossils. Memoirs of the Association of Australasian Palaeontologists 32, 7-41.
Strand, T. 1929: The Cambrian beds of the Mjøsen District in Norway. Norsk Geologisk Tidsskrift 10, 105-121.

Størmer, L. 1925: On a Lower Cambrian fauna at Ustaoset in Norway. Fennia 45, 12-22.

Topper, T.P., Skovsted, C.B., Brock, G.A. \& Paterson, J.R. 2007: New bradoriids from the lower Cambrian Mernmerna Formation, South Australia: systematics, biostratigraphy and biogeography. Memoirs of the Association of Australasian Palaeontologists 33, 67-100.

Topper, T.P., Skovsted, C.B., Harper, D.A.T. \& Ahlberg, P. 2013: A bradoriid and brachiopod dominated shelly fauna from the Furongian (Cambrian) of Västergötland, Sweden. Journal of Paleontology 87, 69-83.

Vidal, G. \& Nystuen, J.P. 1990: Lower Cambrian acritarchs and the Proterozoic-Cambrian boundary in southern Norway. Norsk Geologisk Tidsskrift 70, 191-222.

Voronova, L.G., Drozdova, N.A., Esakova, N.V., Zhegallo, B.A., Zhuravlev, A.Yu, Rozanov, A.Yu, Sayutina, T.A. \& Ushatinskaya, G.T. 1987: lskopaemye nizhnego kembriya gor Makkenzi (Kanada) [Lower Cambrian Fossils of the Mackenzie Mountains (Canada)]. Trudy Paleontologicheskogo Instituta Akademiya Nauk SSSR 224, 1-88. (In Russian).

Walch, J.E.I. 1771: Die Naturgeschichte der Versteinerungen zur Erläuterung der Knorrischen Sammlung von Merkwürdigkeiten der Natur. Dritter Theil. Paul Jonathan Felßecker, Nürnberg, viii + 235 pp.

Walcott, C.D. 1890: The fauna of the Lower Cambrian or Olenellus Zone. Tenth Annual Report of the United States Geological Survey, 509-761.

Weidner, T. \& Nielsen, A.T. 2015: Agraulos longicephalus and Proampyx? depressus (Trilobita) from the Middle Cambrian of Bornholm, Denmark. Bulletin of the Danish Geological Society 63, 1-11.

Wenz, W. 1938: Handbuch der Paläozoologie. Band 6: Gastropoda, Teil 1: Allgemeiner Teil und Prosobranchia. Borntraeger, Berlin, viii + $240 \mathrm{pp}$.

Westergård, A.H. 1936: Paradoxides oelandicus beds of Öland. Sveriges Geologiska Undersökning C 394, 1-66.

Westergård, A.H. 1953: Non-Agnostidean Trilobites of the Middle Cambrian of Sweden III. Sveriges Geologiska Undersökning C 526, 1-53

Westrop, S.R. \& Landing, E. 2000: Lower Cambrian (Branchian) trilobites and stratigraphy of the Hanford Brook Formation, southern New Brunswick. Journal of Paleontology 74, 858-878.

Whittington, H.B. 1988: Hypostomes and ventral cephalic sutures in Cambrian trilobites. Palaeontology 31, 577-609.

Whittington, H.B. 1990: Articulation and exuviation in Cambrian trilobites. Philosophical Transactions of the Royal Society of London 329, 27-46.

Whittington, H.B. 1997: Morphology of the exoskeleton. The trilobite body. In Kaesler, R.L. (ed.): Treatise on invertebrate paleontolgy. Part O. Arthropoda 1. Trilobita, Revised. Volume 1, Geological Society of America and University of Kansas, Boulder, Colorado and Lawrence, Kansas, pp. 1-59 \& pp. 87-135.

Wiman, C. 1903: Studien über das Nordbaltische Silurgebiet. Bulletin of the Geological Institution of the University of Upsala 6, 12-76.

Zenker, J. 1833: Beiträge zur Naturgeschichte der Urwelt. Organische Reste (Petrefacten) aus der Altenburger Braunkohlen-Formation, dem Blankenburger Quadersandstein, jenaischen bunten Sandstein und böhmischen Uebergangsbirge, mit 6 illuminirten Kupfertafeln. Mauke, Jena, 67 pp.

Zhou, B. \& Xiao, L. 1984: Early Cambrian Monoplacophorans and Gastropods from Huainan and Huoqiu Counties (Anhui Province). Professional Papers of Stratigraphy and Palaeontology 13, 125-140. (In Chinese). 
Żylińska, A. 2013: The oldest Cambrian trilobites from the Holy Cross Mountains, Poland: taxonomic, stratigraphgic and biogeographic reappraisal. Acta Geologica Polonica 63, 57-87.

Żylińska, A. \& Masiak, M. 2007: Cambrian trilobites from Brzechów, Holy Cross Mountains (Poland) and their significance in stratigraphic correlation and biogeographic reconstructions. Geological Magazine 144, 661-686.

Żylińska, A. \& Szczepanik, Z. 2009: Trilobite assemblages from the Lower-Middle Cambrian boundary interval in the Holy Cross Mountains (Poland). Acta Geologica Polonica 59, 413-458.

Żylińska, A., Kin, A. \& Nowicki, J. 2013: Application of morphometric tecniques for taxonomic revision of Berabichia oratrix (Orłowski, 1985) (Trilobita, Cambrian) from the Holy Cross Mountains, Poland. Geodiversitas 35, 505-528. 